\title{
O aprendizado organizacional na implementação de políticas públicas industriais em três estados nordestinos
}

Antônio Glauter Teófilo Rocha

\section{Introdução}

Nos anos 1990, o governo brasileiro, motivado, entre outros fatores, por uma crise fiscal aguda e influenciado pelo dogma neoliberal, abdicou do uso de políticas industriais e de políticas de desenvolvimento regional como forma de intervir ativamente no processo de desenvolvimento do País. Nesse contexto, observa-se uma descentralização não planejada dessas políticas, ou seja, elas emergem no nível subnacional. Governos estaduais e municipais aventuram-se na criação de programas locais de atração de indústrias via incentivos fiscais e financeiros, acirrando as disputas por investimentos no ambiente federativo. Essas disputas foram intensificadas ao longo da década de 90 e ficaram conhecidas como as guerras fiscais, dando margem ao surgimento de um polêmico e polarizado debate sobre o assunto no Brasil. Por um lado, essas políticas são vistas como a pior alternativa possível para a intervenção do setor público no processo de inversão privada (CAVALCANTI; Prado, 1998, p. 42) ou como políticas 
do desperdício (ArbIx, 2002). Por outro, são defendidas como instrumentos para acelerar o crescimento de regiões periféricas e diminuir desigualdades regionais quando os governos nacionais se ausentam dessas funções (Amaral FiLHo, 2003).

Essas análises procuram avaliar tal fenômeno por perspectivas que envolvem racionalidade exclusivamente econômica, quando não puramente tributarista. Entretanto, essa questão envolve aspectos políticos e institucionais que dificilmente poderiam ser satisfatoriamente capturados por esse tipo de análise. O desenvolvimento dessas políticas de atração de investimentos é um processo evolucionário e os processos de tomada de decisão envolvidos na definição de seus rumos não são norteados apenas por determinantes econômicos, nem mesmo puramente racionais. Além disso, eles têm negligenciado um aspecto fundamental do processo de implementação dessas políticas: os governos aprendem, as políticas evoluem. De fato, no desenvolvimento desta pesquisa, foi possível constatar que existe um relevante processo de aprendizado envolvido nessa implementação que permanece inexplorado pelos estudiosos do assunto. Esse processo parece produzir um ambiente dinâmico e inovativo que vem estimulando a realização de contínuas reformas no conteúdo e na forma das políticas em questão.

Apesar de reconhecer a importância do atual debate sobre as guerras fiscais, não é objetivo deste trabalho revisar ou julgar o mérito da literatura sobre guerras fiscais, e, tampouco, tentar fornecer elementos empíricos ou teóricos que venham confirmar ou negar a validade de suas conclusões. Neste artigo, procura-se ampliar o conhecimento atual sobre a dinâmica dos processos de aprendizado na implementação de políticas públicas - e, em particular, das políticas industriais implementadas pelos estados da Bahia, do Ceará e de Pernambuco - e tentase entender se e como esse aprendizado pode acelerar ou inibir o desenvolvimento de melhores intervenções dos estados subnacionais na promoção de seu desenvolvimento em curto, médio e longo prazo. Busca-se entender, em especial, os aspectos políticos envolvidos nesses processos e como eles influenciam a evolução e os resultados dessas políticas.

Para atingir esses objetivos, realizaramse estudos de casos em três estados brasileiros que têm feito uso intensivo de políticas industriais descentralizadas desde o início da década de 90: Ceará, Bahia e Pernambuco. No desenvolvimento desses estudos de casos, foram utilizados dois instrumentos principais de pesquisa: pesquisa documental e realização de entrevistas semi-estruturadas com os principais atores envolvidos no processo de implementação das políticas estudadas. Este artigo está organizado como segue: na segunda seção, é feita uma apresentação sucinta do processo de implementação das políticas industriais do Ceará, da Bahia e de Pernambuco na última década e meia; na terceira seção, apresentam-se as evidências e os principais achados sobre os processos de aprendizado ocorridos na implementação das políticas industriais desses três estados, analisando especialmente os aspectos políticos neles envolvidos; por fim, na quarta seção, são apresentadas as principais implicações de política e sugestões para futuras pesquisas que decorrem deste trabalho.

\section{A implementação das políticas industriais do Ceará, da Bahia e de Pernambuco}

Nesta seção, apresenta-se o processo de implementação das políticas industriais 
do Ceará, da Bahia e de Pernambuco, abordando, de forma bastante resumida, as características e a evolução dessas políticas ao longo da última década e meia ${ }^{1}$.

\section{O caso do Ceará}

Diferentemente da Bahia e de Pernambuco, o desenvolvimento industrial do Ceará entre 1950 e 1970 deveu-se basicamente à iniciativa privada local. Os grandes empreendimentos de investidores de fora da região induzidos pelos incentivos federais localizaram-se quase que exclusivamente na Bahia e em Pernambuco. Entre 1960 e 1978, a Superintendência do Desenvolvimento do Nordeste (Sudene) aprovou projetos industriais para cerca de 200 empresas do Ceará, equivalendo apenas a $7,2 \%$ do investimento total aprovado para o Nordeste, contra 43,5\% da Bahia e 21,7\% de Pernambuco.

O Ceará, nesse período, foi excluído das alternativas locacionais consideradas pelos grandes empreendedores externos e, também, pelo governo federal. Essa exclusão deveu-se, entre outras razões, ao fato de o estado não dispor ainda de condições mínimas de infra-estrutura para o funcionamento industrial. Havia deficiência no suprimento de energia elétrica; insuficiência de infra-estrutura portuária, rodoviária e de comunicações; além de fatores como a inexistência de economias externas, o reduzido mercado local e a maior distância entre mercados fornecedor e consumidor de bens intermediários e finais. Com isso, o Ceará ficou em posição de desvantagem em relação aos demais estados brasileiros. Seus indicadores econômicos e sociais no final dos anos 1970 evidenciavam essa defasagem ${ }^{2}$.

Do ponto de vista da industrialização do estado, o quadro começa a mudar com o esforço industrializante do governo Virgílio Távora, 1963-1966, na medida em que este tirou o Ceará do isolamento do fornecimento federal de energia hidrelétrica - sistema Chesf (Companhia Hidroelétrica do São Francisco) de Paulo Afonso - quando prolongou o abastecimento da região do Cariri para Fortaleza. Esse esforço tem continuidade em seu segundo mandato, de 1979 a 1982, quando se constroem os distritos industriais na região metropolitana de Fortaleza e implementase a lei que deu lugar à política de atração

\section{“(...) atuação dos governos da Bahia, do Ceará e de Pernambuco no fomento às atividades industriais vão além da pura e simples concessão de incentivos fiscais às empresas que desejam neles se instalar."}

de investimentos e ao Fundo de Desenvolvimento Industrial (FDI).

O esforço industrializante ganha novo impulso a partir de 1987, com a chegada dos "jovens empresários" ao poder. Com a vitória nas eleições para governador do estado de 1986 de uma nova elite política ${ }^{3}$ sobre as velhas oligarquias que governaram o estado por décadas (os coronéis) ${ }^{4}$, inicia-se nova fase na administração pública 
do estado, mais eficiente e mais profissional. Assim, a partir de 1987, o Ceará iniciou um processo de profunda reestruturação político-administrativa com repercussões na estrutura produtiva e no crescimento. O governo realizou reformas no estado, ajustou as contas públicas e recuperou a credibilidade e a capacidade de investimento. Desde então, o Ceará vem se destacando dentre os estados brasileiros pelas reformas, ajustes e políticas bem sucedidas que tem implementado, pelo incremento significativo nos investimentos públicos e privados e pela melhoria de seus indicadores econômicos.

Essa transição é reflexo tanto de fatores históricos como dos resultados de um conjunto coerente de políticas públicas implementadas pelas novas elites políticas locais. $\mathrm{Na}$ área econômica, a melhoria nos indicadores tem sido, geralmente, atribuída ao sucesso do governo na implementação dos programas de atração de indústrias. Como resultado desses programas, somente entre janeiro de 1995 e agosto de 2003, foram instalados no estado 372 novos empreendimentos industriais, correspondendo a um investimento acumulado de aproximadamente $\mathrm{R} \$ 3,7$ bilhões (aproximadamente 2,35\% do PIB do estado em 2001) e criando mais de 83 mil empregos diretos na indústria (SECREtaria de Desenvolvimento Econômico do Estado do Ceará - SDE). Os principais setores contemplados com esses investimentos foram o coureiro-calçadista, metal-mecânico, alimentício, têxtil e de confecções.

Por um lado, apesar desses bons resultados no fomento à industrialização, a política industrial do estado tem sido conservadora no que se refere aos mecanismos de política utilizados, pois seus programas, na prática, são baseados fundamentalmente no estímulo à instalação de novos empreendimentos industriais no estado por meio de incentivos fiscais e financeiros e da vantagem de mão-de-obra mais barata. Mas, por outro lado, ao longo da implementação dessa política, o governo do estado vem tentando, progressivamente, sofisticar e aperfeiçoar seus mecanismos de política industrial. Nesse sentido, para dar suporte a seu processo de industrialização, passou a investir intensiva e continuamente na construção de infra-estrutura moderna ${ }^{5}$ e, também, na qualificação profissional de sua mão-de-obra ${ }^{6}$. Além disso, tem procurado, continuamente, aperfeiçoar seus programas de incentivos fiscais por meio de adaptações do modelo original.

Com a implementação dessa política, o Ceará não só saiu na frente na disputa pelos investimentos que ressurgiam no País nos anos 1990, mas foi um dos estados nordestinos mais bem sucedidos na atração de indústrias para seu território durante toda essa década. Talvez por isso a política do Ceará tenha sido geralmente citada como caso de sucesso, levando diversos outros estados brasileiros a adotá-la como modelo para o desenvolvimento de suas próprias políticas industriais, a exemplo da Paraíba e do Rio Grande do Norte.

Todavia, nos últimos anos, esse modelo foi bastante questionado e discutido pelo próprio governo do Ceará, ocasionando várias tentativas recentes de reformas. Devese considerar, porém, que as motivações para essa mudança de postura em relação à política não decorrem apenas de razões técnico-econômicas relacionadas aos resultados da política, mas também de toda dinâmica que envolve jogos de interesses (internos e externos), disputas de poder e conflitos entre as secretarias, órgãos e agências do governo. 
Nas próximas duas subseções deste artigo, para explicar melhor a dinâmica da implementação da política industrial do Ceará, sua história será divida em duas fases distintas. A primeira abrange toda a década de 90 , retratando uma época em que o estado foi pioneiro e especializou-se nessa política, tornando-a soberana entre suas ações de desenvolvimento. A segunda fase reflete uma situação mais avaliativa e crítica em relação à política, marcada por uma série de tentativas de reformas.

\section{A primeira fase: pioneirismo e especialização}

Em 1979, com a criação do Programa Estadual de Incentivos para a Promoção Industrial do Ceará, no segundo governo de Virgílio Távora (1979-1982), o estado já começa a criar instrumentos estaduais de incentivo à industrialização. No final desse mesmo ano, foi criado o Fundo de Desenvolvimento Industrial do Ceará $(\mathrm{FDI})^{7}$, cujo objetivo principal era promover o desenvolvimento das atividades industriais em todo território cearense. Quando foi criado, o FDI pretendia ser uma forma complementar dos incentivos concedidos pelos programas de desenvolvimento regional e industrial do governo federal, operacionalizados principalmente pela Sudene e pelo Banco do Nordeste. Assim, já no início desse governo, foram concedidos incentivos estaduais na forma de contratos de financiamento do FDI para várias empresas industriais do estado.

Contudo, com o desmantelamento das políticas nacionais de desenvolvimento industrial e regional nos anos seguintes e, também, devido à falta de capacidade de investimento do Estado ${ }^{8}$, ainda na gestão de Virgílio Távora, muitos desses contratos já não vinham sendo cumpridos pelo governo cearense. No governo seguinte, de Gonzaga Mota (1982-1986), o programa de incentivos fiscais à indústria foi totalmente abandonado, inclusive com a suspensão dos contratos de incentivos fiscais vigentes.

Somente a partir das mudanças político-administrativas iniciadas no estado em 1987, esse mecanismo de política passou a ser sistemática e efetivamente utilizado. Assim, já no início do primeiro governo de Tasso Jereissati (1986-1990), o estado reinicia sua política de incentivos à indústria, retomando os contratos de incentivos fiscais que haviam sido "desativados" nos governos anteriores. Nesse período inicial, a atuação do governo no domínio industrial era ainda tímida no que se refere à atração de novos empreendimentos. Com a retomada dos investimentos privados no País, porém, a partir de 1993/1994, o estado assume postura bem mais ativa no incentivo à industrialização, utilizando agressivamente incentivos estaduais para atrair indústrias do sul e sudeste do País e, também, do exterior.

Na década de 90, o Ceará foi pioneiro no uso intensivo de incentivos fiscais e financeiros para atrair investimentos externos - acendendo o estopim da chamada guerra fiscal entre os estados do Nordeste. Essa condição de first mover na disputa pelos empreendimentos industriais dos anos 90 não foi obra exclusiva do acaso, devendose à existência de certas precondições naquele momento, no estado.

É possível acreditar que duas dessas precondições foram especialmente importantes para o estado largar na frente nessa disputa. A primeira, comumente aclamada, diz respeito ao já mencionado novo contexto político-administrativo instaurado no estado no final dos anos 80, que possibilitou a recuperação de sua imagem e a retomada dos investimentos públicos. 
A segunda precondição, geralmente ignorada, diz respeito ao aprendizado acumulado pelas elites políticas (os jovens empresários políticos) e técnicas do estado nas discussões e iniciativas nascidas no contexto do III Pólo Industrial do Nordeste ${ }^{9}$ e desdobradas no desenvolvimento do Programa Estadual de Incentivos para a Promoção Industrial do Ceará, a partir do final da década de 70. As discussões sobre esses programas, por solicitação do então governador Virgílio Távora, tiveram como fórum principal de debates o Centro Industrial do Ceará, que mais tarde veio a ser o berço das mudanças que ocorreriam no estado. Portanto, tudo leva a crer que a nova elite política já estava bastante familiarizada com essa agenda de política quando assumiu o poder em 87. Além disso, os principias mecanismos institucionais para a implementação dessa agenda já haviam sido criados $^{10}$.

Entretanto, sem desprezar a importância de largar na frente na atração dos investimentos, acredita-se que o bom desempenho do estado na atração de indústrias decorreu, entre outras coisas, da especialização da Secretaria de Desenvolvimento do Estado (SDE) na execução dessa estratégia por mais de uma década. A SDE, no decorrer de toda a década de 90, dedicou-se quase que exclusivamente ao programa de atração de indústrias do estado. Aos poucos, ela foi desenvolvendo expertise para prospectar investimentos e negociar com investidores, ajustando os mecanismos de incentivo e refinando suas rotinas operacionais. Portanto, a experiência e o learning-by-doing ajudaram a SDE a alcançar resultados expressivos em termos de atração de investimentos para o Ceará.

A eficiência na execução dessa estratégia aumentou com o uso. Por exemplo, os executivos dessa agência acumularam conhecimento sobre os setores industriais considerados estratégicos para o estado (calçados, têxtil, confecções, metal-mecânico etc.), passando a conhecer suas dinâmicas, seus principais atores, seus gargalos e as oportunidades emergentes. Esse conhecimento aumentou significativamente a eficiência e a eficácia da SDE tanto na prospecção de oportunidades que emergiam nesses setores como também no convencimento de empresários a se instalarem no Ceará.

Concomitantemente, o ganho de eficiência na execução dessa política também intensificou seu uso, resultando em um ciclo retroalimentativo que tanto aumentou a eficiência no uso como também o próprio uso. Entretanto, relembrando Levitt e March (1988), existe sempre o risco de a organização cair na "armadilha da competência", ou seja, quando uma organização obtém resultados favoráveis com rotinas, procedimentos ou estratégias inferiores, ela acumula mais experiência, tornando a experiência com outras opções superiores não recompensantes de usar. Mas como saber se essa estratégia adotada pelo estado é inferior ou superior, boa ou ruim? Como determinar se ela está sendo bem sucedida ou não?

De fato, a diferença entre sucesso e falha ou entre bom e ruim nem sempre é óbvia. Ao longo do processo de implementação de tal política, na maioria das vezes, essa distinção foi baseada muito mais em interpretação de pessoas ou grupos do que em fatos ou evidências resultantes de avaliações puramente técnicas. A prova disso é que a primeira avaliação técnica da política só foi realizada no final de 2000, quase uma década após o início de seu uso intensivo. Todavia, nunca houve consenso dentro do governo (nem na sociedade) em torno dessa 
estratégia. Interpretações divergentes sobre a efetividade da política de atração de indústrias via incentivos fiscais sempre coexistiram. O que levou então uma interpretação a se sobrepor a outra?

Durante toda a década de 90, a interpretação dominante dentro do governo do Ceará sobre essa estratégia foi a de que ela era a melhor estratégia possível para transformar a situação de atraso econômico e social do estado. Creio que dois fatores foram determinantes para a predominância dessa interpretação. $\mathrm{O}$ primeiro, ligado aos resultados imediatos e visíveis da política, ou seja, a grande quantidade de empresas atraídas para o estado a cada ano e seus milhares de empregos diretos gerados. $\mathrm{O}$ segundo está relacionado ao poder político daqueles que, dentro e fora do governo, apoiavam e defendiam a política. Como seus resultados de longo prazo eram difíceis de serem antecipados com precisão, os grupos de interesses politicamente mais fortes - favoráveis a ela - fizeram prevalecer sua interpretação positiva da política.

$\mathrm{Na}$ verdade, esses dois fatores não são estanques, pois se reforçam mutuamente. Assim, quanto melhores e mais visíveis eram os resultados imediatos da política, mais poder político era conferido a seus executores e defensores. Quanto maior o poder político deles, mais recursos e autonomia lhes eram dados para executar a política. Esse ciclo retroalimentativo motivou cada vez mais a especialização da SDE na implementação dos programas de incentivos fiscais a indústria. Essa especialização, por um lado, aumentou sua eficiência na atração de investimentos para o estado, mas, por outro lado, reduziu seu interesse em experimentar formas alternativas (substitutas ou complementares) de promover o desenvolvimento do estado.
Além disso, vale ressaltar que essa política possui pelo menos dois trunfos que, de certa forma, têm garantido sua sustentabilidade. Em primeiro lugar, ela é utilizada em larga escala como forma de atender a crescente demanda dos prefeitos, deputados e líderes políticos regionais por geração de emprego e renda em seus municípios. Em segundo lugar, por meio dela, o governo estreita sua relação com o setor empresarial, abrindo um canal

"O aprendizado organizacional não pode ser visto como simples processo cognitivo de indivíduos ou grupos, especialmente no processo de formulação e implementação de políticas públicas."

de comunicação e interação entre ele e os empresários, incluindo os proprietários das novas empresas atraídas pelos incentivos. O apoio desses empresários foi importante para a continuidade do projeto político das elites políticas dominantes, principalmente, na arrecadação de doações para fundos de financiamento de campanhas eleitorais ${ }^{11}$. Entretanto, dado o perfil mais profissional e tecnocrático da nova elite 
política cearense, provavelmente esses fatores políticos per si não seriam suficientes para motivar essa elite a ingressar intensamente na implementação de uma política tão polêmica sem uma justificativa técnica e econômica, no mínimo, convincente.

Do ponto de vista técnico-econômico, a SDE, principal defensora da política, argumentava que, dada a falta de políticas nacionais de correção das desigualdades regionais do País e as condições edafoclimáticas extremamente desfavoráveis do Ceará, somente o adensamento do complexo industrial do estado por meio da atração das indústrias que migravam do sul e sudeste do País mudaria o quadro de estagnação econômica vivido pelo estado nas últimas décadas. Isso resultaria em uma redução significativa da situação de pobreza em que vivia a maioria da população cearense, melhorando sensivelmente os indicadores econômicos e sociais do estado. A SDE defendia ainda a hipótese de que, nesse caso, a prática de redução ou isenção de ICMS em larga escala não comprometeria a receita tributária do estado, porquanto esses incentivos seriam dados a empreendimentos industriais que não se instalariam no Ceará, caso eles não fossem concedidos. Nesse sentido, sem perda real de arrecadação e a um custo muito baixo, poder-se-ia utilizar esse mecanismo para atrair investimentos de outras regiões brasileiras - e, também, do exterior - e acelerar o processo de industrialização do Estado.

Essa proposta, de fato, nunca foi unanimemente aceita pelo governo. A Secretaria da Fazenda do estado, desde o início, principalmente por seu corpo técnico, manifestou-se insatisfeita com esse tipo de política, pois temia que ela comprometesse a arrecadação e a saúde financeira do estado no médio ou longo prazo. Além disso, muitos questionavam a sustentabilidade dessa estratégia, pois temiam a não permanência dessas empresas no estado após o término do prazo dos incentivos.

Todavia, apesar do ceticismo dos fazendários e das inúmeras críticas de alguns setores da sociedade, por quase uma década essa política foi soberana como principal estratégia de desenvolvimento do Ceará. Durante toda a década de 1990, nenhuma outra política recebeu tanta atenção e recursos do governo cearense ${ }^{12}$. Creio que o poder político da SDE e os bons resultados de curto prazo da política ajudaram a manter sua primazia. Nesse período, nem mesmo os setores do governo mais insatisfeitos com a política opunham-se aberta e veementemente a ela, pois, tamanha era a supremacia da política que seria arriscado se posicionar contra uma estratégia que parecia tão vantajosa e cujos resultados imediatos eram alardeados, dentro e fora do estado, como um dos grandes feitos do governo cearense na área econômica. Todavia, ainda no final da década, essa situação parece ser alterada e inicia-se uma fase mais crítica em relação aos programas de atração de indústrias do estado. Esse novo contexto e os principais impactos sobre a condução da política industrial do Ceará são objetos da próxima seção.

\section{A segunda fase: conflitos e reformas}

No final dos anos 1990, o estado começa a apresentar indícios de comprometimento de sua saúde financeira e de certo desequilíbrio fiscal. Nesse cenário, a Secretaria da Fazenda (Sefaz) e a Secretaria de Planejamento e Coordenação (Seplan) ${ }^{13}$ intensificaram suas críticas à política de incentivos fiscais, questionando duramente a hipótese da SDE de que ela não comprometeria a saúde financeira do estado. Eles argumentavam que a situação 
era de alerta em relação à política, pois, em 1999, os repasses para o Fundo de Desenvolvimento Industrial já representavam cerca de $15 \%{ }^{14}$ da arrecadação de ICMS do estado. Por outro lado, a SDE e os defensores da política argumentavam que, de fato, a elevada relação FDI/ICMS apresentada nos últimos anos não representava indicação real de impacto negativo da política de incentivos nas finanças do estado, pois, já que esses novos empreendimentos não se instalariam no Ceará caso os incentivos fiscais não fossem concedidos, essa receita adicional não ocorreria.

Contudo, a hipótese da SDE de inexistência de impacto financeiro da política não se confirmou por três motivos principais. Primeiro porque as empresas locais passaram a pressionar o governo para obter as mesmas reduções ou isenções de ICMS dadas aos investidores externos, argumentando que se não os recebessem não poderiam concorrer com as novas empresas em igualdade de condições. Portanto, para preservar a competitividade da indústria local, o governo foi forçado a ceder a muitas dessas pressões e a conceder benefícios fiscais também para empresas cearenses, o que afetou a base de arrecadação real do estado. Segundo, a concorrência entre os estados iniciou um verdadeiro leilão por investimentos que inflou a renúncia fiscal, levando muitas vezes à isenção total do ICMS. Terceiro, devido à obrigatoriedade de destinar parte da arrecadação do ICMS para fundos constitucionais $^{15}$, o governo do estado teve que arcar com o ônus de repassar para esses fundos uma arrecadação que de fato ocorria apenas escrituralmente, diminuindo assim sua flexibilidade no uso dos recursos orçamentários do estado.

Além disso, segundo a Seplan, nem todos os indicadores sociais do estado refletiam melhorias tão significativas quanto as esperadas. O problema da pobreza da maioria da população persistia e o da desigualdade parecia ter aumentado. Os diferenciais de renda ainda eram elevados, sendo, por exemplo, a renda média da população rural $\mathrm{R} \$ 74,00$ (Iplance, 1999) inferior a um terço da renda média da Região Metropolitana de Fortaleza R \$ 58,00 (Iplance, 1999). De acordo com essa agência, uma das raízes do problema residia na estrutura setorial desigual do PIB e da PEA, que aumentara durante a década de 90.

Nesse contexto, o governador do estado $^{16}$ assumiu uma postura mais crítica em relação à política de incentivos fiscais. Essa postura, de certa forma, sinalizava a emergência de uma nova configuração de forças entre as agências do governo. Aparentemente, apesar de ainda forte politicamente, a SDE começava a ceder espaço para os setores do governo mais críticos em relação aos incentivos fiscais, especialmente a Seplan, que liderava o grupo dos insatisfeitos com a política.

No entanto, talvez a relação entre os possíveis resultados negativos da política e o enfraquecimento político da SDE não seja tão óbvia e unidirecional. É possível que, por razões diversas ${ }^{17}$, tenha ocorrido primeiro o enfraquecimento político dessa secretaria, possibilitando assim que esses aspectos negativos fossem relacionados à política. De qualquer forma, a partir daí, a configuração de forças dentro do governo foi alterada e começou a ser delineada uma nova fase na execução dessa política, mais crítica, mais avaliativa e, de certa forma, mais reformista.

Como conseqüência desses eventos, ocorridos no final dos anos 1990, em 2000, por determinação do próprio governador do estado, foi realizada uma primeira 
avaliação da política de incentivos fiscais do estado por uma equipe de consultores externos. Essa avaliação tinha como objetivo principal encontrar formas de reduzir os custos ${ }^{18}$ e de aumentar os benefícios dessa política. Como resultado dessa primeira avaliação, foi proposto um novo modelo para a política de atração de indústrias do estado. De acordo com esse modelo, a política deveria ser reorientada no sentido de não mais se destinar apenas à atração de novos empreendimentos industriais, mas, sobretudo, de fixá-los por meio da inserção e da vinculação desses empreendimentos aos diversos conjuntos industriais do estado. Dessa maneira, a nova política visaria não só ordenar a concessão de incentivos, ajustando e reduzindo seus benefícios fiscais, mas também criando ambientes eficientes de produção ${ }^{19}$.

Mas esse novo modelo, mesmo não conseguindo a aprovação da SDE, foi apoiado pela Seplan e pelos outros críticos da política. Devido aos conflitos entre as partes envolvidas nessa questão, na prática, a maior parte das recomendações da avaliação e a nova metodologia de concessão de incentivos parecem nunca ter sido realmente implementadas pelo governo, pois dependiam substancialmente da aceitação e do empenho da SDE, que executava a política.

A despeito da validade e da pertinência (ou não) dos aspectos técnicos do modelo proposto, o fato de submeter a política a uma avaliação externa naquele momento representou um sinal de insatisfação e desconfiança do governador em relação ao rumo que vinha sendo dado à política de desenvolvimento do estado e, principalmente, revelou indícios de uma provável perda de autonomia da SDE em sua condução, além de indicar a predisposição do governo em frear o ritmo de implementação da política de incentivos, reduzindo portanto a capacidade de atuação da SDE e, também, seus recursos futuros. Por isso, independentemente dos aspectos técnicos, dificilmente essa secretaria aceitaria a reforma.

Apesar de não ter sido implementada na íntegra a maior parte das recomendações diretas dessa primeira avaliação, seus resultados indiretos foram importantíssimos nas mudanças que viriam a ocorrer nos anos seguintes. Esse trabalho deu início a um processo contínuo de discussão e avaliação da política de desenvolvimento do estado, especialmente a política industrial. Desses resultados indiretos, talvez um dos mais importantes tenha sido a criação do Centro de Estratégias de Desenvolvimento do Estado do Ceará $(\mathrm{CED})^{20}$. Esse centro era uma espécie de think tank que deveria cumprir uma dupla missão: a primeira era acompanhar e promover a melhoria contínua da política de incentivos fiscais do estado; a segunda era de funcionar como um centro gerador de idéias e estratégias inovadoras para o desenvolvimento sustentável do estado, que complementassem a política de incentivos fiscais.

As ações do CED tinham um viés para a pesquisa, formulação e avaliação de políticas, mas, na prática, abrangiam também um trabalho exaustivo de articulação e negociação com os diversos atores envolvidos na implementação dessas políticas. O órgão logo se viu inserido em um contexto político turbulento e cheio de conflitos, em que a consecução de seus objetivos dependia não só da capacidade de gerar novas idéias ou estratégias, mas também de negociar suporte político para elas e para sua própria sobrevivência.

Por um lado, o surgimento do CED intensificou o debate sobre a estratégia de 
desenvolvimento do estado, levando-o para um nível tecnicamente mais sofisticado. A entrada de um think tank no processo acelerou o aprendizado com a inserção de conhecimentos oriundos da academia ou extraídos de outras experiências nacionais e internacionais, complementando e sistematizando o learning-by-doing. Isso não só sofisticou a discussão sobre o aperfeiçoamento da política de incentivos fiscais, mas trouxe também para o debate o questionamento sobre a necessidade de adensar essa estratégia com o uso de novos mecanismos de política como o estímulo ao aumento da capacidade de inovações tecnológicas por parte do sistema produtivo; o fortalecimento das empresas locais de base tecnológica; o apoio ao empreendedorismo, às micro e pequenas empresas e seus arranjos produtivos locais; e a organização e a animação das principais cadeias produtivas do estado.

Por outro lado, a entrada do CED no sistema acirrou ainda mais o conflito em torno da política de atração de indústrias do estado. A SDE sentiu-se ameaçada de perder sua autonomia e discricionariedade na formulação e implementação dessa política, pois a nova instituição era vinculada à Seplan, que defendia maior controle e moderação no uso dos incentivos fiscais.

Nos anos que seguiram a criação do CED, a interação entre essas instituições (SDE, CED, Seplan, Sefaz etc.) foi intensa e, apesar de conflituosa, desencadeou um processo em que novas idéias, hipóteses e propostas surgiram e foram discutidas, aperfeiçoadas, negociadas e depois implementadas ou abandonadas. Essa dinâmica institucionalizou o exercício contínuo de avaliação, revisão e aperfeiçoamento das políticas e estratégias de desenvolvimento do estado.
Exemplo disso é que, passados pouco mais de dois anos daquela primeira grande revisão da política de incentivos, o governador do estado solicitou a formação de um grupo de trabalho envolvendo os representantes máximos de todas as agências ligadas direta ou indiretamente à área de desenvolvimento ${ }^{21}$ para fazerem nova reforma na política industrial do estado, consolidando o aprendizado adquirido em mais de dez anos de

"(...) o aumento

da habilidade de

aprender a aprender

dos governos não

depende apenas

de aumentar a

capacidade de

aquisição de

conhecimento (...),

mas, também, de

criar mecanismos

eficientes de difusão,

socialização e

armazenamento

deste aprendizado."

implementação da política. A segunda reforma envolveu um longo e conflituoso processo de discussão e negociação entre essas instituições. Discutiu-se não só uma maior seletividade na concessão dos incentivos fiscais - inclusive com redução dos valores dos incentivos - mas também a necessidade e a forma de consolidar a transição de uma simples política de atração de investimentos para uma política 
industrial mais consistente e completa, menos dependente de incentivos fiscais no médio e longo prazo.

Esse grupo elaborou uma proposta que, depois de discutida por mais de quatro meses em um fórum, do qual participavam todo o grupo e também o governador do estado, deu origem à Nova Política Industrial do Ceará, oficializada pelo Decreto $\mathrm{n}^{\circ}$ 26.546, de 04 de abril de 2002. Com esse decreto, o governo do Ceará procurava codificar e institucionalizar o aprendizado ocorrido nesse processo de revisão e também da primeira década de implementação da política ${ }^{22}$.

Essa nova política constava basicamente de dois tipos de medidas. O primeiro tipo estava relacionado a ajustes no mecanismo de atração de indústrias por meio de incentivos fiscais e financeiros, em que o estado já havia se especializado na última década e já tinha significativo know-how acumulado. O segundo envolvia mudanças mais profundas e com maior grau de incerteza. Implicava adoção de medidas de políticas menos convencionais, nas quais o governo tinha pouca ou nenhuma experiência. Assim, nos meses seguintes, entre a publicação desse decreto e o final de 2002, além dos ajustes que proporcionaram maior controle sobre os programas de incentivos fiscais, pouco se avançou no desenvolvimento e implementação dessas outras medidas de política. $\mathrm{Na}$ prática, a política industrial do estado continuou baseada quase que exclusivamente na atração de empreendimentos industriais por meio dos incentivos fiscais.

Em 2003, inicia-se uma nova gestão no governo do estado ${ }^{23}$ e o novo governador substitui o comando da Secretaria de Desenvolvimento Econômico. Essa mudança aparentemente sinalizava que o governo manteria a tendência de uso mais "racional" e comedido da política de incentivos fiscais, pois o secretário de desenvolvimento econômico anterior sempre foi o defensor mais ferrenho da política, resistindo duramente a todas as reformas que se tentou implementar nos anos anteriores. De fato, essa tendência confirmou-se, pois o governo continuou com a filosofia de utilização mais controlada da política, adotando uma série de medidas que visavam reduzir os custos da política.

Entretanto, apesar de ter diminuído o ritmo da política de incentivos fiscais, o novo governo continuou tendo esse instrumento como o carro-chefe da estratégia de desenvolvimento do Estado. Nesse período, o governo pôs em prática muitos dos ajustes da política de incentivos fiscais propostos nos anos anteriores e inviabilizados pela resistência da SDE. Além disso, o governo procurou, por meio de um sistema de pontuação, balancear os custos relativos aos incentivos com os benefícios trazidos pela empresa atraída. Nesse sistema de pontuação, passou-se a diferenciar os projetos em função dos benefícios e impactos introduzidos por eles no interior da economia local, ou seja, quanto maiores os impactos, maiores serão os benefícios, desde que não ultrapasse a "regra de ouro" de 75\% do valor a ser recolhido (Dias; Holanda; Amaral Filho, 2003). Ainda mais recentemente, visando isolar os impactos dos incentivos sobre os gastos vinculados, o governo mudou a forma de concessão de crédito para capital de giro para dilação de prazo. Contudo, pouco se avançou na formulação e na implementação de outros tipos de medidas de política para promoção do desenvolvimento do estado. O governo prosseguiu fortemente dependente da política de atração de indústrias via incentivos fiscais, que continuou a consumir a maior parte 
dos seus investimentos e dos seus recursos na área de desenvolvimento.

\section{O caso da Bahia (1991-2003): melhoria contínua e consolidação com a Ford}

Ao longo da década de 90, a política industrial da Bahia evoluiu para uma posição de destaque na configuração de uma nova tentativa de alavancar o desenvolvimento do estado. De acordo com os executivos do governo baiano, distinguem-se três fases principais na evolução dessa política. $\mathrm{Na}$ primeira fase, a partir do início da década de 90, o governo inicia timidamente essa política, com a criação do Programa de Promoção do Desenvolvimento da Bahia (ProBahia), um programa geral que consistia na concessão de financiamentos, com juros subsidiados, de um percentual do ICMS para os novos empreendimentos industriais que fossem atraídos para o território baiano $^{24}$. Esse programa, principalmente nos anos de 1994 e 1995, teve como principal resultado a expansão da base produtiva anterior, tanto com a implantação de novas plantas como pela ampliação das existentes, principalmente no setor petroquímico. Nessa fase, os investimentos foram bastante concentrados nos pólos já existentes, situados na Região Metropolitana de Salvador.

Num segundo momento, a partir de 1996, além de dar continuidade ao ProBahia, o governo começa a desenvolver programas setoriais mais focados, como o Programa Estadual de Desenvolvimento da Indústria de Transformação Plástica (Bahiaplast); o Programa Estadual de Desenvolvimento da Mineração, da Metalurgia e da Transformação do Cobre (Procobre); o Programa de Incentivo à Produção Têxtil e de Confecções (Profibra); os programas de apoio ao pólo de informática, eletrônica e telecomunicações de Ilhéus; entre outros. Nesses programas, além de priorizar setores específicos e estratégicos para o estado, o governo passou a utilizar um novo mecanismo de incentivos fiscais, o sistema de crédito presumido do $\mathrm{ICMS}^{25}$. Esse novo sistema possibilitava ao governo ser mais agressivo no uso de incentivos fiscais sem comprometer tanto a saúde financeira do estado. Um dos principais resultados dessa fase foi a implantação da indústria de bens leves de consumo (calçados, têxtil, confecções, alimentos e bebidas). Ademais, ao contrário do que ocorreu na fase anterior, os investimentos dessa fase aconteceram de forma menos concentrada espacialmente, pois o governo baiano muitas vezes os induziu para que fossem implantados em municípios isolados do semi-árido baiano.

Por fim, no final dos anos 1990, devido ao significativo impacto do esforço de atração da Ford no orçamento do estado, na tentativa de minimizar os custos e aumentar os benefícios de longo prazo de sua política de atração de indústrias, o governo baiano iniciou um período de intensa discussão e revisão dessa política, emergindo a partir daí uma terceira fase em sua implementação, na qual o governo mudou o enfoque para uma maior seletividade dos incentivos e para uma tentativa ainda mais explícita de verticalização e adensamento de cadeias produtivas. Esse processo de revisão resultou na criação do Programa de Desenvolvimento Industrial e de Integração Econômica do Estado da Bahia (Desenvolve), cujo objetivo principal é, expressamente, diversificar a matriz industrial e agroindustrial do estado com a integração e a verticalização das cadeias produtivas estratégicas da região ${ }^{26}$.

Observa-se, portanto, que a política de incentivos fiscais cresceu em importância 
dentro da estratégia de desenvolvimento do estado, tornando-se seu carro-chefe em meados da década de 1990. Além disso, aos poucos ela foi sendo aperfeiçoada e sofisticada, por exemplo, voltando-se para a atração de produtores de bens de consumo final, buscando diversificar a economia do estado e tentando preencher e adensar suas cadeias produtivas. Com isso, o governo baiano procura reduzir a instabilidade provocada pela concentração da indústria do estado na produção de commodities petroquímicas, herdada do processo de industrialização das décadas passadas. O coroamento dessa estratégia veio com a instalação da indústria automobilística no estado, que após duas tentativas frustradas do governo baiano ${ }^{27}$, consolidou-se com a vinda da Ford que, como visto, abriu caminho para uma maior integração da indústria do estado em direção aos bens finais de consumo durável de alto valor agregado, diversificando assim das commodities intermediárias.

Entretanto, esse processo de evolução não ocorreu de forma automática, nem resultou de esforços intelectuais puramente racionais e técnicos dos tecnocratas ou políticos baianos. Também foram envolvidos fatores políticos e institucionais como as disputas entre os diversos órgãos da estrutura administrativa do estado, ligadas direta ou indiretamente à implementação da política, na defesa de seus interesses e crenças ao longo de todo o processo. Portanto, o balanço de forças entre essas unidades tem sido também fator crucial na definição dos rumos da política.

Entre esses órgãos, novamente a disputa de interesses principal recaiu sobre a secretaria que executa a política, a Secretaria de Indústria Comércio e Mineração (SICM), e a Secretaria da Fazenda do Estado. A primeira defendia sua autonomia no uso dos incentivos fiscais para atrair investimentos para o território baiano e a segunda tentava conciliar essa política com a administração financeira e tributária do estado. Contudo, se comparada à disputa entre as agências na implementação da política de incentivos fiscais do Ceará, a interação entre as agências da Bahia foi bem menos conflituosa e mais técnica, mas a divergência de posições e de interesses das agências não deixou de ser extremamente importante no processo de evolução da política.

No decorrer dos anos 1990, o que se observa é, também, uma especialização da agência executora da política - a SICM - na estratégia de atrair empreendimentos industriais utilizando incentivos fiscais e financeiros. Assim como ocorreu no Ceará, os resultados de curto prazo alcançados com essa política incentivaram a intensificação de seu uso e o aprendizado gerado pelo learning-by-doing aumentou a eficiência e a eficácia da agência na atração de investimentos. Em poucos anos, essa política passou a concentrar a maior parte dos investimentos do governo da Bahia na área de desenvolvimento, tornando todas as outras ações dessa área no máximo coadjuvantes no esforço do governo de retomada do crescimento econômico do estado. Nesse período, a esmagadora maioria dos recursos humanos e financeiros ${ }^{28}$ do governo baiano para a área de desenvolvimento, especialmente da SICM, passou a ser consumida por essa política.

Contudo, apesar dessa especialização, em decorrência da densidade e complexidade do aparato burocrático baiano, não deixou de haver, ao longo de todo o processo, um esforço interno significativo do governo para reflexão, discussão e avaliação da política. A atuação de órgãos 
como a Sefaz, a Secretaria de Estado de Planejamento e da Ciência e Tecnologia (Seplantec) e a Agência de Fomento do Estado da Bahia (DesenBahia) - por meio da realização de estudos e avaliações e, principalmente, na formação de grupos de trabalho junto com a SICM - contribuiu expressivamente para controle e aperfeiçoamento da política industrial baiana.

Desses órgãos, o mais atuante no acompanhamento, na avaliação e no controle da política, fazendo contraponto à especialização da SICM em atrair empreendimentos industriais externos via incentivos fiscais e financeiros, foi a Sefaz. Essa Secretaria, uma das chamadas "ilhas de eficiência” do estado, era politicamente forte e possuía burocracia bastante qualificada. Sua missão principal era zelar pelo equilíbrio fiscal do estado, recuperado no início da década de 90, no terceiro governo de Antônio Carlos Magalhães. Nesse sentido, dada a natureza no mínimo duvidosa dos impactos da política de atração de indústrias sobre as finanças do estado $^{29}$, essa Secretaria assume postura crítica e bastante cautelosa em relação a ela desde o início de sua implementação. Criou, inclusive, já no início dos anos 1990, uma assessoria especializada em incentivos fiscais ${ }^{30}$. Essa assessoria tinha como funções principais: acompanhar a política de atração; avaliar seus impactos no orçamento do estado; ajudar a SICM a desenvolver e aperfeiçoar os mecanismos fiscais e financeiros de incentivo às indústrias, entre outras. Em decorrência disso, o governo baiano, comparado aos governos do Ceará e de Pernambuco, parece ter sido o mais eficiente e ágil em desenvolvimento, adaptação e calibração dos mecanismos de incentivos fiscais e financeiros, amenizando os impactos da política nas finanças do estado. Somente entre 1991e 2000, o governo do estado experimentou três tipos distintos desses mecanismos: o sistema de financiamento do ICMS (operações triangulares); o de crédito presumido e o de dilação de prazos.

Já a Secretaria de Planejamento, que no Ceará foi um dos órgãos mais atuantes no acompanhamento e controle da política de atração de indústrias do estado, na Bahia, teve uma atuação limitada. Sua participação no processo de desenvolvimento e implementação da política de incentivos fiscais baiana ocorreu de forma bastante tímida, basicamente, por meio da realização de estudos e por participações marginais em grupos de trabalhos específicos. Acredita-se que essa participação acanhada da Seplantec deveu-se, em parte, ao fato de que ela acumulava, além da elaboração do plano plurianual e do orçamento do governo, diversas outras funções de natureza operacional, como a realização de obras importantes para o estado ${ }^{31}$. Esse tipo de atividade, além de sobrecarregar os recursos humanos da instituição, também gerava importantes dividendos políticos para ela, tornando, talvez, o envolvimento com a política de atração de indústrias de importância secundária para a instituição.

Um exemplo emblemático da contribuição dessas agências ocorreu no processo de revisão da política de incentivos fiscais, no final dos anos 1990 e início da atual década, que originou o Programa Desenvolve, atualmente condutor da política de atração de indústrias do estado. Nessa época, esboçava-se um quadro de apreensão em alguns governos de estados nordestinos sobre a sustentabilidade de suas políticas de incentivos fiscais, inclusive na Bahia. Por um lado, havia a necessidade urgente de os governos repensarem seus mecanismos de atração de investimentos 
à luz das mudanças que vinham ocorrendo no marco regulatório fiscal brasileiro ${ }^{32}$. Por outro, o acirramento da competição entre algumas unidades da federação pela atração de investimentos e o elevado custo dessas políticas para os estados apontavam para a necessidade de revisão dos mecanismos tradicionais de concessão de incentivos fiscais.

Surgiu então, no âmbito das reuniões do Conselho Nacional de Política Fazendária (Confaz) ${ }^{33}$, uma proposta de formação de um grupo de trabalho que envolveria representantes das secretarias da fazenda e de planejamento dos estados do Nordeste - inicialmente Bahia, Ceará, Paraíba e Pernambuco - para tentar esboçar uma proposta de superação das distorções criadas pela disputa por investimentos da chamada guerra fiscal ${ }^{34}$. Esse grupo de trabalho interestadual passou a discutir a criação de um modelo unificado de concessão de incentivos fiscais para os estados do Nordeste. Os pontos de partida dessa discussão foram o novo modelo de política de incentivos fiscais que vinha sendo desenvolvido pelo governo do estado do Ceará e o modelo de classificação de projetos que estava sendo trabalhado pelo Banco de Desenvolvimento do Estado da Bahia (Desenbanco) ${ }^{35}$.

O grupo interestadual, após várias rodadas de discussão e negociação, elaborou uma proposta inicial desse modelo unificado para ser discutida com os demais estados do Nordeste. O modelo, de certa forma, funcionaria como um mecanismo de coordenação das políticas de incentivos fiscais desses estados, estabelecendo faixas diferenciadas ${ }^{36}$ de incentivos que balizariam essas políticas. Além disso, o modelo preconizava uma postura mais seletiva dos estados na atração de indústrias e também a adoção de um novo mecanismo de concessão de incentivos fiscais, baseado na dilação de prazos do pagamento do $\mathrm{ICMS}^{37}$.

Segundo a proposta, os governos passariam a adotar ainda uma nova metodologia para a seleção de projetos e para a definição dos benefícios fiscais a serem concedidos a cada um deles. Dessa forma, o prazo e o percentual dos incentivos a serem concedidos passariam a ser definidos de acordo com um índice de aderência do projeto à matriz de desenvolvimento industrial de cada estado $^{38}$, estabelecendo critérios mais técnicos e seletivos para a concessão dos incentivos. Esses critérios levariam em conta fatores como a repercussão do projeto na geração de empregos diretos e indiretos; a capacidade de desconcentração espacial dos investimentos; a contribuição para integração e verticalização de cadeias produtivas do estado; o grau de desenvolvimento tecnológico dos processos produtivos e de assimilação de novas tecnologias; e a capacidade de exportação do empreendimento, bem como os impactos ambientais do projeto.

Ao final do processo de discussão dessa proposta, o modelo unificado de incentivos não chegou a ser aceito por todos os estados do Nordeste, pois, entre outras razões, nem os estados menos desenvolvidos da região aceitavam reduzir a oferta de incentivos ${ }^{39}$, nem as secretarias de desenvolvimento econômico do Ceará, principalmente, e de Pernambuco eram simpáticas à proposta. A proposta foi então totalmente abortada pela maioria dos estados. Todavia, a burocracia baiana continuou o trabalho de aperfeiçoamento do modelo internamente. Naquele momento, já havia sido iniciado no governo da Bahia um processo de grande interlocução da SICM, que executava a política, com a Sefaz, a DesenBahia e a 
Seplantec, procurando articular os distintos interesses e posturas em relação à política de incentivos do estado ${ }^{40}$, não obstante ter falhado a iniciativa de unificação das políticas dos estados nordestinos. Manteve-se então o grupo de trabalho interinstitucional que havia participado das discussões com os outros estados para repensar a política de incentivos baiana e rever seus mecanismos de atuação. Dos trabalhos desse grupo, originou-se o Programa Desenvolve, que adotou a maioria das mudanças prevista naquela proposta de modelo unificado.

Esse exemplo demonstra a importância da interação dos órgãos governamentais baianos no processo de desenvolvimento e implementação da política de atração de indústrias do estado. $\mathrm{O}$ aprendizado interativo dessas agências ajudou, portanto, a moldar a política, contemplando tanto os aspectos racionais e cognitivos como também os políticos. Durante o desenvolvimento dos trabalhos do grupo montado para rever a política, a todo momento seus membros concorriam pela supremacia dos interesses de suas agências nas disputas internas do grupo. Por exemplo, a SICM contestava veementemente a proposta da Sefaz e do Desenbanco de utilização do modelo matemático da matriz de aderência para classificação dos projetos e definição dos percentuais e prazos de incentivos fiscais, pois isso diminuiria sua autonomia e discricionariedade para negociar os incentivos fiscais com as empresas a serem atraídas.

$\mathrm{Na}$ verdade, essas disputas técnicas e políticas entre os órgãos do governo não se manifestaram apenas nos trabalhos desse grupo, mas ocorreram durante todo o processo de formulação e implementação da política de atração de indústrias do estado desde o início da década de 90 e foram decisivas em sua evolução ao longo dessa década, influenciando em seus objetivos, conteúdo, forma, instrumentos e, conseqüentemente, em seus resultados de curto, médio e longo prazo.

\section{O caso de Pernambuco (1991-003): início tardio e tentativa de catch up recente}

Dentre os estados do Nordeste que ingressaram na empreitada de implementar políticas industriais ativas nos anos 1990, Pernambuco foi um dos últimos a fazer uso, em escala significativa, dessas políticas para tentar alavancar seu crescimento econômico, ou seja, foi um dos últimos a ingressar agressivamente na chamada guerra fiscal. Todavia, diante do cenário de declínio econômico que o estado já vivia há mais de uma década, impulsionado pelo mau desempenho de seu setor industrial, por que Pernambuco sairia atrasado na guerra fiscal? A resposta para a questão, entre outras coisas, envolve tanto determinantes relacionados ao contexto político instável de Pernambuco, como também aspectos ligados à situação precária das finanças públicas e à deterioração do aparato burocrático estatal. Além disso, no período 1995-1998, o então governador Miguel Arraes privilegiou um modelo de desenvolvimento diferente daquele que vinham perseguindo a Bahia e o Ceará; sua prioridade era tentar solucionar o problema da pobreza rural por meio de ações de assistência direta às populações mais pobres do estado, e não deu tanta importância à política industrial, como fizeram os dois outros estados.

$\mathrm{Na}$ verdade, desde o início da década de 90, o governo de Pernambuco, em maior ou menor grau, já vem buscando desenvolver mecanismos de política para tentar incentivar o setor industrial. Sua 
estratégia, em linhas gerais, é bastante semelhante às estratégias da Bahia e do Ceará, ou seja, está baseada na atração de investimentos externos (ou retenção dos locais) por meio da concessão de incentivos fiscais e financeiros e de investimentos em infra-estrutura.

Entretanto, é preciso distinguir duas fases bem distintas no que se refere ao uso de mecanismos de política industrial no Estado no período recente (a partir de 1991). Numa primeira fase, que envolve as gestões de Joaquim Francisco (1991-1994) e de Miguel Arraes (1995-1998), os mecanismos institucionais foram desenvolvidos, a política passou a ser implementada, mas não se atingiram resultados expressivos no que se refere à atração de investimentos para o território pernambucano; pelo contrário, o estado chegou a perder diversas indústrias para os estados vizinhos. A segunda fase, marcada por atuação mais efetiva do governo, é iniciada na primeira gestão de Jarbas Vasconcelos (1999-2002) e tem continuidade em seu segundo mandato (2003-2006). Nessa fase, Pernambuco realizou grandes investimentos em infraestrutura, passou a utilizar incentivos fiscais em maior escala e conseguiu atrair uma gama considerável de novos investimentos para o estado. Nas subseções seguintes, descreve-se sucintamente essas duas fases.

\section{A primeira fase (1991-1998): saindo atrasado?}

No início dos anos 1990, Pernambuco começa a esboçar a intenção de desenvolver um esforço endógeno de alavancagem do crescimento do estado via política industrial. Já no primeiro ano de governo de Joaquim Francisco, foi instituído o Fundo Cresce Pernambuco (Funcresce), pela Lei no 10.649, de 25 de novembro de 1991. Esse fundo tinha "o objetivo de apoiar e incrementar o desenvolvimento industrial do estado" (art. $1^{\circ}$ ). Por meio dele, o governo ofertava financiamentos subsidiados de parte do ICMS, disponibilizava terrenos e executava obras de infra-estrutura e instalações para tentar atrair novas indústrias para o estado e também para incentivar a ampliação ou modernização das indústrias existentes ${ }^{41}$. Os incentivos ofertados pelo Funcresce eram equivalentes aos incentivos ofertados pelos outros estados da região, mas o programa não obteve grande êxito na atração de novas indústrias para o território pernambucano, pois aquele era um período de poucos investimentos no País e, além disso, as alternâncias de poder político no estado geravam insegurança nos investidores.

A partir de 1995, no governo seguinte, apesar de o novo governador, Miguel Arraes, não ser favorável à idéia de concessão de incentivos fiscais a empresas privadas, a Agência de Desenvolvimento Econômico de Pernambuco (AD/Diper) e a Secretaria de Indústria e Comércio, valendo-se da pressão dos empresários locais por incentivos ${ }^{42} \mathrm{e}$ da opinião pública favorável, convenceram-no a criar um programa de atração de indústrias para o estado $^{43}$. Assim, pela Lei no 11.288 , de 22 de dezembro de 1995, instituiu-se o Programa de Desenvolvimento de Pernambuco (Prodepe), que tinha a finalidade de fomentar o desenvolvimento industrial, especialmente em relação aos setores considerados relevantes e prioritários para a economia do estado, mediante a concessão de financiamentos nos term $\mathrm{s}$ previsto nessa lei $\left(\operatorname{art.} 1^{\circ}\right)$. Para consecuç $\mathrm{O}$ do programa, o governo criou o Fundo Prodepe, que, nos mesmos moldes do Funcresce, viabilizaria os incentivos a sere $\mathrm{m}$ concedidos às indústrias atraídas para o 
estado. Todavia, mesmo com a retomada dos investimentos no País a partir do Plano Real, o governo pernambucano não conseguiu ser muito eficaz na atração de novos investimentos para o estado. No final do governo de Arraes, em 1999, enquanto na Bahia e no Ceará, por exemplo, os financiamentos para as empresas incentivadas já passavam de $8 \%$ e $14 \%$, respectivamente, da arrecadação de ICMS dos estados, em Pernambuco esse valor era de $2 \%$ apenas, aproximadamente.

O fraco desempenho de Pernambuco na atração de indústrias nessa primeira fase da política, além da escassez inicial de investimentos no País nos primeiros anos da década de 1990, decorreu de uma série de fatores inter-relacionados. Em primeiro lugar, o contexto político instável do estado provocava desconfiança nos investidores quanto à disposição e capacidade do governo de honrar seus compromissos com as empresas que fossem atraídas. Em segundo lugar, a situação precária das finanças públicas do estado não permitia ao governo realizar os investimentos necessários em infra-estrutura, nem honrar pontual e fielmente os compromissos do fundo com as empresas. Em terceiro lugar, a descontinuidade administrativa no governo do estado inibiu a formação de uma burocracia profissional e qualificada, dificultando assim o processo de especialização e aprendizado na implementação de sua política industrial. Além disso, a cada mudança de governo ocorria também uma perda significativa de memória nas agências do governo que lidavam com a política, pois todo o corpo gerencial e a parte mais qualificada do corpo técnico eram substituídos a cada nova gestão. Essa perda de memória não era ainda maior devido à presença de diversos consultores privados ${ }^{44}$ que atuavam na interface entre governo e investidores que, de certa forma, armazenavam parte dessa memória ${ }^{45}$ e transmitiam aos novos corpos técnicos e gerenciais dos órgãos do governo.

Portanto, resumindo, nessa primeira fase, apesar de ter desenvolvido os mecanismos institucionais e iniciado o processo de implementação de programas de atração de investimentos via incentivos fiscais e financeiros, o governo de Pernambuco não conseguiu consolidar uma política industrial efetiva na atração dos investimentos necessários à recuperação do setor industrial do estado. Seus resultados na atração e retenção de investimentos foram bem inferiores aos que a Bahia e o Ceará conseguiram. O setor industrial continuou perdendo participação na economia do estado e contribuindo para a manutenção da situação desconfortável da economia pernambucana, praticamente estagnada durante a década de 90.

\section{A segunda fase (pós-1999): tentativa de} catch up

Tão logo se inicia a primeira gestão de Jarbas Vasconcelos (1999-2002), o governo de Pernambuco põe em curso uma série de mudanças que vieram a criar um contexto favorável para a utilização mais efetiva da política de atração de investimentos do estado. Ao longo de 1999, o governo implementou uma reforma administrativa ampla, promovendo rigoroso ajuste fiscal baseado em um maior controle dos gastos públicos, especialmente aqueles com pessoal e custeio da máquina administrativa. Com o saneamento das contas públicas e a venda da Companhia Energética de Pernambuco (Celpe), o governo retomou os investimentos públicos $^{46}$, praticamente parados há mais de uma década no estado. Iniciou, também, a implementação de um abrangente Programa 
de Valorização do Servidor (PVS), visando a profissionalização e qualificação dos servidores públicos estaduais. Além disso, começou a recuperar a credibilidade junto aos investidores, que vêem no novo governo um agente mais confiável e mais amistoso. Todas essas mudanças criaram as condições para uma atuação ativa e consistente do governo pernambucano na implementação de política industrial mais efetiva.

Portanto, no final dos anos 1990, Pernambuco passou a apresentar as mesmas condições favoráveis que a Bahia e o Ceará apresentavam no início da década para uma intervenção mais sistemática e eficaz no fomento ao setor industrial. Nesse contexto, por meio da Lei $\mathrm{n}^{\circ}$ 11.675, de 11 de outubro de 1999, o governo realiza uma abrangente reforma no programa de atração de indústrias do estado, o Programa de Desenvolvimento de Pernambuco (Prodepe), que passa então a ser conhecido como Prodepe II. Dentre as principais inovações que essa reforma trouxe, destacam-se:

- o incentivo a atividades não industriais pelo Prodepe, como o estímulo ao comércio importador atacadista de mercadorias do exterior e às centrais de distribuições;

- o início do uso de um novo mecanismo de incentivo fiscal, o do crédito presumido;

- uma maior hierarquização dos incentivos, focando-os para "os agrupamentos industriais estruturados em cadeias produtivas formados por empresas localizadas no Estado" (Lei no 11.675). O governo passou a concentrar maior carga de incentivos para as cadeias da agroindústria (exceto a sucroalcooleira e de moagem de trigo), metal-mecânica e de material de transporte, eletroeletrônica, farmoquímica, bebidas e minerais não metálicos (exceto cimento e cerâmica vermelha).
Contudo, a principal inovação dessa nova fase foi, de fato, a mudança de postura do governo em relação à política de atração de investimentos. Pernambuco passou a adotar uma postura mais pró-ativa e agressiva na atração de investimentos. A política industrial passou a assumir papel de destaque na agenda de desenvolvimento do governo pernambucano, contando inclusive com o total apoio e incentivo do novo governador, que na campanha eleitoral tecia severas críticas a seu oponente por achar que o estado havia entrado timidamente na guerra fiscal e que o governo Arraes assustava os investidores. Além disso, a agência que implementa a política - a AD/Diper - fortaleceu-se na estrutura do novo governo e adquiriu mais motivação para executar a política, pois passou a receber mais créditos pela atração dos investimentos.

Essa nova postura do governo pernambucano, associada a seus significativos investimentos em infra-estrutura, aumentou consideravelmente a eficácia do estado na atração de investimentos. Enquanto no período de 29/09/1996 a 09/12/1998 (no governo Arraes) foram aprovados 224 projetos de incentivos do Prodepe (investimento previsto de $\mathrm{R} \$ 1,9$ bilhões), entre 30/06/1999 e 25/10/2002 (no primeiro governo de Jarbas) foram aprovados 516 projetos (investimento previsto de $\mathrm{R} \$ 3,8$ bilhões) ${ }^{47}$. Nessa nova fase, o governo aprovou mais do que o dobro do número de projetos (e também do investimento previsto) em relação ao governo anterior. Além disso, a renúncia fiscal, que era de menos de 2\% em 1999, passou para cerca de $8 \%$ no final de $2002^{48}$, o que também comprova o maior empenho e disposição do governo para atrair investimentos via incentivos fiscais ${ }^{49}$ (Sefaz/SDE). 
Todavia, assim como na Bahia e no Ceará, não existe unanimidade a respeito da política de incentivos fiscais no governo pernambucano. No estado, também é nítido o conflito de interesses entre a agência que executa a política de incentivos (SDE, AD/Diper) e o órgão que controla as finanças do governo (Sefaz). Mas, vale ressaltar que, em Pernambuco, mesmo entre os que executam a política, o que predomina no governo é um discurso mais reativo, ou seja, tanto os políticos quanto a burocracia pernambucana alegam que o estado precisa entrar agressivamente na guerra fiscal para não perder sua base industrial para outros estados do Nordeste. Diferentemente da maioria dos executivos dos governos do Ceará e da Bahia, que defendem abertamente a efetividade de suas políticas de incentivos como forma de reduzir o atraso de suas economias em relação aos estados do Sul e Sudeste, 100\% dos entrevistados no governo de Pernambuco apregoaram (pelo menos na retórica) que a política de atração de indústrias via incentivos fiscais é, na verdade, uma estratégia de desenvolvimento de segunda categoria ${ }^{50}$ para o estado e que ele a utiliza como forma de defesa contra os efeitos da guerra fiscal.

\section{Fatores cognitivos e políticos moldando as políticas industriais da Bahia, do Ceará e de Pernambuco}

Nos estudos de casos realizados nesta pesquisa, constatou-se que a atuação dos governos da Bahia, do Ceará e de Pernambuco no fomento às atividades industriais vão além da pura e simples concessão de incentivos fiscais às empresas que desejam neles se instalar. Além de aperfeiçoarem continuamente os modelos de política de atração de indústrias originais, eles têm, de várias formas, tentado incorporar aos mecanismos tradicionais de incentivos fiscais outros tipos de medidas menos artificiais de política industrial ${ }^{51}$. Os governos desses estados têm, portanto, promovido contínuas reformas no conteúdo e na forma de suas políticas, revelando importante processo de aprendizado envolvido em suas implementações.

Se, por um lado, as políticas de atração de indústrias desses estados são ainda fortemente dependentes de incentivos fiscais, ainda ocorrem leilões de incentivos nas disputas dos estados por investimentos (maximizando os incentivos para as empresas) e essas políticas representam altos custos para os governos, por outro verifica-se também que elas não são constituídas apenas por incentivos fiscais, mas envolvem ainda expressivos investimentos na ampliação e na modernização da infraestrutura desses estados e, também, esforços significativos em educação tecnológica (para o trabalho) e extensão tecnológica para a indústria.

Além disso, os governos em foco começam a privilegiar: uma maior seletividade na concessão dos incentivos, avaliando mais criteriosamente os projetos de investimentos apresentados pelas empresas; o desenvolvimento de mecanismos institucionais de avaliação e controle de suas políticas de atração de indústrias e de acompanhamento das empresas incentivadas; uma orientação para adensamento de cadeias produtivas e fortalecimento de clusters locais; esforços para criação de setores estruturantes (Ford, na Bahia, Siderúrgica, no Ceará) e, ainda, algumas experiências embrionárias de desenvolvimento de medidas de política voltadas para o apoio a Micro e Pequenas Empresas (MPEs) organizadas em arranjos produtivos locais 
(APLs) e para o fomento a empresas de base tecnológica e a setores de serviços modernos.

Entretanto, quando se iniciaram os estudos de campo desta pesquisa, foi encontrada uma realidade contraditória. Por um lado, a maioria dos estudiosos das políticas de atração de investimentos dos estados subnacionais brasileiros argumentava que as suposições necessárias para um território obter ganhos reais com essas políticas eram "heróicas e irreais", pois seria necessário, por exemplo, que os governos desses estados pusessem em prática detalhadas análises dos impactos gerados por empreendimento a ser atraído, avaliando cuidadosamente os elementos de custobenefício envolvidos. Fato esse considerado irreal, pois, as informações de que os governos dispõem são incompletas (e assimétricas em relação às empresas) e, sobretudo, porque as burocracias desses estados não teriam nem capacidade técnica nem motivação para realizarem essas análises.

Por outro lado, de acordo com as entrevistas preliminares realizadas na Bahia, no Ceará e em Pernambuco, constatou-se que essa suposição de completa apatia e ineficiência da burocracia governamental desses estados não era realidade absoluta, tampouco generalizável. Nas agências envolvidas com formulação, implementação e avaliação dessas políticas foi constatada a existência de um proeminente processo de aprendizado de indivíduos e grupos que contrariava a suposição da incapacidade da burocracia estatal de aperfeiçoar essas políticas. Com base nessa constatação, percebeu-se que um importante aspecto da implementação das políticas estava sendo ignorado: o aprendizado.

Nesse contexto, acreditou-se que seria extremamente relevante entender se, como e em que grau o aprendizado de indivíduos e grupos dentro do governo poderia, de fato, interferir na efetividade das políticas industriais dos governos, melhorando a qualidade de seus resultados em curto, médio e longo prazo. Contudo, explorando esse processo (de aprendizado) em maior profundidade, percebeu-se que o aprendizado de indivíduos e grupos isoladamente dentro do governo não parece garantir efetiva mudança nas ações do governo, ou seja, o aprendizado desses indivíduos e grupos nem sempre se transforma em aprendizado organizacional (do governo). Mas, por que isso acontece? É possível acreditar que isso tem a ver com os aspectos políticos do processo de aprendizado organizacional dos governos.

$\mathrm{O}$ assunto do aprendizado, embora pouco estudado na literatura sobre política industrial, encontra-se bastante desenvolvido em outras áreas do conhecimento, como nas literaturas sobre aprendizado organizacional, economia neoschumpeteriana e policy learning. Contudo, nessa literatura, geralmente, considera-se que o "bom aprendizado" ocorre em um clima de abertura no qual o comportamento político é minimizado.

Essa suposição é, contudo, bastante questionável. O aprendizado organizacional não pode ser visto como simples processo cognitivo de indivíduos ou grupos, especialmente no processo de formulação e implementação de políticas públicas. As experiências de implementação das políticas industriais da Bahia, do Ceará e de Pernambuco chamam a atenção para a importância dos aspectos políticos envolvidos nos processos de aprendizado ocorridos na implementação dessas políticas. Nesse contexto, o aprendizado organizacional mostra-se como um processo no qual aspectos políticos e 
cognitivos interagem sob as restrições de arranjos institucionais específicos.

$\mathrm{Na}$ implementação das políticas industriais da Bahia, do Ceará e de Pernambuco, raros foram os casos em que o conhecimento adquirido por indivíduos ou grupos dos órgãos desses governos foi convertido - sem reduções, alterações ou distorções significativas em sua essência ou sem expressivas defasagens no tempo em aprendizado organizacional, ou seja, foi armazenado, difundido e socializado dentro desses governos a ponto de afetar seu processo de tomada de decisão e provocar mudanças nessas políticas. Além do processo cognitivo, existem também processos políticos envolvidos. Esses processos tanto podem filtrar, como retardar e até mesmo impedir a assimilação organizacional do aprendizado de indivíduos ou de grupos; outras vezes, podem até acelerá-la.

Essas experiências mostram que nem a assimilação do conhecimento consagrado pela literatura, nem aquele adquirido ao longo da implementação das políticas por indivíduos ou grupos se traduzem de forma imediata e automática em aprendizado organizacional. As novas idéias antes de serem aceitas ou rejeitadas - parcial ou integralmente - passam por longos e muitas vezes conflituosos processos de negociação e barganha política dentro da estrutura do governo e da sociedade, envolvendo os diferentes grupos de interesses e diferentes coalizões entre eles. $\mathrm{O}$ resultado final é um mix entre o que foi aprendido pelos indivíduos ou grupos e o que se mostrou politicamente viável ou aceitável naquele momento, dada a configuração de forças internas e externas envolvidas no processo de negociação política. Nesse ambiente, aprendizado, conhecimento ou idéias sem suporte político - independentemente de seus méritos - dificilmente se tornam ações concretas; dificilmente são convertidos em aprendizado organizacional.

Tome-se como exemplo o processo de assimilação organizacional, pelo governo do Ceará, do conhecimento adquirido e acumulado por indivíduos e grupos das agências que participaram do processo de avaliação e revisão de sua política industrial nos primeiros anos da década atual. No ano 2000, foi realizada uma primeira avaliação da política de atração de indústrias do estado por uma equipe de consultores externos, servindo de base para uma primeira revisão dessa política. Desse processo resultou uma proposta de um novo modelo para a política de atração de indústrias do estado. O novo modelo, entre outras coisas, tentava adicionar à política de atração de indústrias cearense uma lógica mais elaborada de organização industrial, baseada em lições oriundas da literatura contemporânea de desenvolvimento e de experiências nacionais e internacionais. Nele, a concessão de incentivos passaria a ser, por exemplo, orientada para o adensamento das cadeias produtivas e o fortalecimento dos embriões de clusters do estado, pois, segundo os autores da proposta, à medida que esses fatores fossem fortalecidos, reduzir-se-ia a necessidade de oferecer incentivos fiscais e seriam criados incentivos não artificiais à fixação desses investimentos no estado.

Entretanto, esses novos conhecimentos - orientação para adensamento das cadeias produtivas e fortalecimento de clusters apesar de estarem em sintonia com a literatura contemporânea e terem sido aceitos e exaustivamente defendidos pelos consultores externos e por alguns setores do governo, não foram assimilados como 
aprendizado organizacional (do governo) de forma a se tornarem instrumentos efetivos de mudança na política industrial do estado naquele momento, não obstante terem entrado na retórica do governo. A despeito de sua pertinência ou não, esse aprendizado não ocorreu e nem foi transformado em instrumento de mudança porque não havia um ambiente político favorável à sua assimilação, pois essa proposta trazia também uma série de outras medidas que implicariam atuação mais moderada do governo na concessão de incentivos fiscais à indústria, gerando um clima político hostil ao novo modelo. Por um lado, a secretaria que executava os programas de incentivos, a SDE, sentia-se ameaçada de perder sua autonomia, discricionariedade e capacidade de atuação na execução da política industrial do estado. Por sentir-se ameaçada, resistia fortemente ao processo de mudanças que se iniciava. Por outro lado, havia também pressões do setor empresarial - por sua entidade de classe, a Federação das Indústrias do Estado do Ceará (FIEC), e também por meio dos consultores privados que atuavam nessa área - para que esse novo modelo fosse abortado, pois ele contrariava diretamente seus interesses, ou seja, restringia e reduzia os incentivos fiscais $^{52}$. Assim, essa nova lógica de organização industrial só foi incorporada de fato à política industrial do estado alguns anos depois, quando esses fatores políticos adversos foram amenizados.

O exemplo acima ilustrou como fatores políticos podem retardar ou até mesmo impedir a socialização e a assimilação organizacional do aprendizado de pessoas ou grupos dentro dos governos, evitando que novas idéias ou conhecimentos venham a se traduzir em mudanças efetivas nas políticas desses governos. No entanto, muitas vezes, os fatores políticos podem também acelerar o processo de aprendizado organizacional nos governos. Em Pernambuco, por exemplo, em 1999, quando ocorreu mais uma alternância de poder entre grupos políticos antagônicos no comando do executivo estadual saindo Miguel Arraes e entrando Jarbas Vasconcelos - criou-se no estado um ambiente em que os fatores políticos estimulavam, ao invés de inibir, essa socialização e assimilação organizacional do aprendizado de pessoas ou grupos das agências que lidavam com a política industrial do estado. O clima era extremamente favorável à absorção de novos conhecimentos e à experimentação de novas idéias.

Havia naquele momento um ambiente político favorável a mudanças, e a tecnocracia governamental foi chamada a promover uma reforma abrangente na política de atração de indústrias pernambucana. Nesse contexto, o novo governo iniciou então sua gestão realizando ampla reforma no Programa de Desenvolvimento de Pernambuco (Prodepe ${ }^{53}$. Na verdade, politicamente, aquela era uma época extremamente propícia a mudanças nesse programa, pois, na campanha eleitoral Jarbas teceu severas críticas à política de desenvolvimento do governo de seu oponente, argumentando que Pernambuco estava sendo extremamente prejudicado pela falta de uma política industrial arrojada e consistente que pudesse competir com as políticas de seus estados vizinhos, principalmente Bahia e Ceará. Além disso, o empresariado local há tempos pressionava o governo por mudanças nessa política, reivindicando as mesmas reduções ou isenções de ICMS dadas pelos estados vizinhos a seus concorrentes, argumentando que se não os recebessem não poderiam concorrer com essas empresas 
em igualdade de condições. Assim, nas agências que participavam da formulação e implementação da política industrial do estado, criou-se terreno fértil para o surgimento e experimentação de novas idéias e conhecimentos que pudessem vir a aumentar a efetividade dessa política.

Nessa reforma, consolidada pela Lei $\mathrm{n}^{\circ} 11.675$, de 11 de outubro de 1999, várias foram as inovações adotadas na política industrial do estado em decorrência desse processo acelerado de aprendizado dos primeiros meses do governo de Jarbas. Entre elas, destacam-se: a mudança de postura do governo em relação à política, adotando postura mais pró-ativa na atração de investimentos e, também, mais agressiva na concessão de incentivos fiscais; a hierarquização dos incentivos fiscais, privilegiando com maiores incentivos os projetos que promoviam o adensamento e a consolidação das cadeias produtivas do estado; o incentivo a atividades não industriais pelo Prodepe (atração de atividades de comércio importador atacadista de mercadorias do exterior e de centrais de distribuições); e a adoção de novo mecanismo de incentivo fiscal, o do crédito presumido.

$\mathrm{Na}$ realidade, à exceção da terceira mudança, as demais não diferem muito dos itens da agenda de reformas das políticas de atração de indústrias da Bahia e do Ceará da época, por exemplo. Entretanto, ao contrário do que ocorreu nesses estados, em Pernambuco o processo de cognição e assimilação organizacional dos novos conhecimentos e implementação das mudanças que deles se originaram ocorreu de forma bem mais acelerada. Em poucos meses, os órgãos do estado os adquiriram, armazenaram e socializaram, incorporando-os rapidamente às normas e códigos - formais e informais - que regem as ações do governo na área de desenvolvimento.
Resumindo, o ambiente político favorável a mudanças foi o grande acelerador desse processo, facilitando a absorção e efetivação pelo governo do aprendizado dos indivíduos e grupos de suas agências.

Outro aspecto que parece ter grande influência nos processos de aprendizado ocorridos na implementação das políticas industriais desses estados é o fato de que os governos não são internamente homogêneos, nem harmônicos. Seus diferentes órgãos, secretarias, agências e instituições competem entre si por melhores posições dentro de sua estrutura formal e informal, lutando por primazia ou apenas pela sobrevivência. Essa disputa dentro do governo desempenha papel importante no processo de aprendizado, às vezes retardando, outras acelerando o aprendizado organizacional, pois, freqüentemente, essas instituições moldam suas estratégias de ação e orientam a criação de competências, em parte, para se habilitarem para as disputas internas e garantirem sua sobrevivência ou primazia. O comportamento dessas instituições - inclusive seu posicionamento nas disputas políticas e ideológicas envolvidas nos processos de mudança - é fortemente influenciado pelas contingências dessas batalhas por posições.

Por exemplo, nos estados estudados nesta pesquisa, as secretarias e as agências diretamente responsáveis pela implementação das políticas de atração de indústrias e as secretarias e instituições que desempenhavam funções de avaliação e controle, como as secretarias da Fazenda e as secretarias de Planejamento, vivenciaram diversos períodos de intensos debates relacionados a essas políticas. Nas disputas, elas defendiam posições que favorecessem a melhoria de seus indicadores de desempenho e, portanto, sua imagem e poder político dentro dos governos. A interação 
dessas secretarias e agências envolveu considerável grau de conflito, pois seus indicadores eram, de certa forma, contraditórios. As instituições executoras das políticas, grosso modo, perseguiam metas relacionadas à quantidade de novas indústrias instaladas no estado, tendo impactos nos gastos públicos e, também, na arrecadação tributária estadual. As secretarias da Fazenda, por outro lado, privilegiavam medidas que garantissem o equilíbrio fiscal desses estados. Assim, a evolução dessas políticas, entre outras coisas, mostrou-se fortemente influenciada pelos embates entre essas instituições que, como geralmente envolviam questões relacionadas aos custos dessas políticas, acabam enveredando pelo caminho de aperfeiçoar os mecanismos e instrumentos de incentivos fiscais, tornandoos menos onerosos para os estados.

No caso específico do Ceará, por exemplo, ocorreram também períodos de intensa interação e conflito entre a Secretaria de Desenvolvimento Econômico do Estado (SDE) e o recém-criado Centro de Estratégias de Desenvolvimento $(\mathrm{CED})^{54}$. Esse último, por ter como elementos centrais de sua missão avaliar, controlar e aperfeiçoar os programas de atração de indústrias do estado e desenvolver outros tipos de medida de política que viessem a complementá-los ou até a substituí-los em médio e longo prazo, já nasceu em estado de conflito com a SDE, que defendia com todas as suas forças a manutenção - e até intensificação - incondicional dos programas de atração de indústrias via incentivos como estratégia principal de desenvolvimento do estado. Assim, durante os anos finais do terceiro mandato de Tasso Jereissati, presenciouse no estado forte embate entre essas instituições que, para defender suas posições e interesses, desenvolveram esforços significativos a fim de se capacitarem para as batalhas técnicas e políticas com o intuito de definirem os rumos da política de desenvolvimento do estado. Os resultados dessas disputas foram, portanto, elementos importantes na configuração da direção e da forma de evolução da estratégia de desenvolvimento do governo cearense naquele período, que, apesar de ainda se manter fortemente dependente dos programas de incentivos fiscais, já começava a ser incrementada com experiências - ainda que embrionárias - de medidas menos convencionais de política industrial e de desenvolvimento, como apoio a MPEs.

Portanto, as experiências da implementação das políticas industriais da Bahia, do Ceará e de Pernambuco evidenciam que, pelo menos, dois aspectos importantes, além da dimensão cognitiva, devem ser considerados na análise do processo de aprendizado na implementação de políticas públicas: os processos de negociação e barganha política entre os grupos de interesse envolvidos e as disputas internas das instituições por posições nos governos. Considerar esses aspectos, além de possibilitar melhor entendimento desse processo, revela a existência de uma estrutura (entendida como as inter-relações entre variáveis-chave que influenciaram o comportamento ao longo do tempo; Senge, 1990) a ele subjacente, que acentua significativa e sistematicamente o desequilibrio do balanço entre o aprendizado que tem impactos predominantemente de curto prazo e o aprendizado que tem impactos sobre questões mais estruturais e de longo prazo, favorecendo o desenvolvimento mais rápido do primeiro em detrimento do segundo. Neste trabalho, denominouse o primeiro de "aprendizado instrumentalista” (aquele em que a ênfase está nas 
técnicas e em como torná-las mais eficientes, que prioriza mudanças incrementais e de curto prazo) e o segundo de "aprendizado experimentalista" (aquele mais reflexivo, criativo, arriscado, que impacta sobre questões mais estruturais, normativas e de longo prazo). O problema é que aperfeiçoar sistematicamente mais os primeiros em relação aos segundos é, provavelmente, mais efetivo em curto prazo, mas potencialmente autodestrutivo em longo prazo.

A tendência em favor do aprendizado que privilegia a melhoria nos resultados de curto prazo, resulta, principalmente, das necessidades e das aspirações predominantemente imediatistas tanto dos grupos de interesse que influenciam o processo de aprendizado organizacional, como das instituições governamentais que disputam posições. Ambos, com o objetivo de garantir sua sobrevivência e prosperidade, são geralmente pressionados a obter bons resultados em curto prazo para fortalecer suas posições nas estruturas de poder e, conseqüentemente, aumentar sua influência e seu poder de barganha. Esse é um processo cíclico, retroalimentativo e cumulativo que, de certa forma, pode aprisionar o aprendizado organizacional a um processo de melhorias excessivamente rotineiras e instrumentais. Além disso, a especialização - motivada, entre outras coisas, pelo learning-by-doing - das secretarias e agências que implementam diretamente as políticas de atração de indústrias desses estados reforça esse processo.

Resumindo, com base nas evidências institucionais dos processos de aprendizado envolvidos na implementação das políticas industriais dos estados da Bahia, do Ceará e de Pernambuco, constata-se: primeiro, que o aprendizado organizacional envolvido na implementação dessas políticas resulta de processos complexos nos quais aspectos políticos e cognitivos interagem sob as restrições de arranjos institucionais específicos, sendo, também, afetados pela dinâmica das disputas por primazia ou por sobrevivência entre instituições concorrentes dentro dos governos; e, segundo, que, devido às necessidades e aspirações predominantemente imediatistas dos atores políticos ${ }^{55}$ envolvidos nesse processo de aprendizagem, o desequilíbrio entre o aprendizado instrumentalista e o aprendizado experimentalista é acentuado, favorecendo o desenvolvimento mais rápido do primeiro em detrimento do segundo. Isso pode significar o aumento da efetividade dessas políticas e do sistema em curto prazo, associada à provável degeneração de sua capacidade de conceber e dar sustentabilidade política às mudanças estruturais necessárias para sua sobrevivência e prosperidade em longo prazo. Contudo, vale ressaltar que os governos não estariam irremediavelmente presos a essa estrutura, pois, como argumenta Senge (1990), as pessoas como parte das estruturas podem mudá-las.

\section{Conclusão: implicações de política e sugestões para pesquisas futuras}

Foram revelados nesta pesquisa dois achados importantes sobre os processos de aprendizado organizacional (dos governos) ocorridos na implementação das políticas industriais da Bahia, do Ceará e de Pernambuco, que, provavelmente, não são privativos desses casos. Em primeiro lugar, que esse aprendizado decorre de processos complexos nos quais aspectos políticos e cognitivos interagem sob as restrições de arranjos institucionais específicos, sendo, também, influenciados pelas disputas entre instituições concorrentes dentro dos 
governos. Em segundo lugar, que, devido a necessidades e anseios predominantemente imediatistas dos atores políticos envolvidos nesse processo, acentua-se o desequilíbrio entre o aprendizado instrumentalista e o aprendizado experimentalista, favorecendo o desenvolvimento mais rápido do primeiro em detrimento do segundo, reduzindo a capacidade desses governos de implementarem mudanças estruturais.

Nesse sentido, dois corpos de literatura são complementados pelos achados desta pesquisa. Primeiramente, ela traz uma perspectiva alternativa de análise - a do aprendizado - para as políticas industriais implementadas pelos estados subnacionais brasileiros, cobertas normalmente pela chamada literatura das guerras fiscais. As evidências da pesquisa mostram que, entre outras coisas, as análises tradicionais desse fenômeno têm negligenciado um aspecto fundamental no processo de implementação dessas políticas: os governos aprendem, as políticas evoluem. Ou seja, o desenvolvimento dessas políticas é um processo evolutivo e seus resultados de curto, médio e longo prazo não são predeterminados pelo seu desenho inicial, mas dependem fortemente do aprendizado ocorrido ao longo de sua implementação. Assim, o sucesso ou o fracasso das estratégias de desenvolvimento desses governos estão muito mais relacionados à sua capacidade de aprender do que, propriamente, à sua eficiência atual na execução dessas políticas ou do atual formato delas. Além disso, os estudos de casos desta pesquisa sugerem ainda que a evolução dessas políticas não ocorre de forma perfeitamente racional e coordenada. A dinâmica de funcionamento desses governos na implementação de suas políticas industriais apresentaram alguns fatos estilizados que parecem desempenhar também um papel fundamental em seus processos de evolução e aprendizado. São eles: as disputas internas nos governos, a especialização das secretarias e das agências executoras dos programas de atração de investimentos e um viés para avanços e melhorias predominantemente instrumentais dessas políticas.

A segunda literatura afetada pelos achados deste trabalho é a própria literatura sobre aprendizado nas organizações, tanto os trabalhos sobre aprendizado organizacional desenvolvidos nas áreas de administração de empresas e de sociologia organizacional como os trabalhos sobre aprendizado nas áreas de desenvolvimento econômico e políticas públicas, tais como os dos economistas neo-schumpeterianos. Nessa literatura, comumente, considera-se que o "bom aprendizado" ocorre em um clima de abertura em que o comportamento político é minimizado. Contudo, de acordo com o observado nesta pesquisa, essa suposição é questionável, especialmente no processo de formulação e implementação de políticas públicas nos governos. Os estudos de casos sobre a implementação das políticas industriais da Bahia, do Ceará e de Pernambuco chamam a atenção para a importância dos aspectos políticos envolvidos nos processos de aprendizado ocorridos na implementação dessas políticas. Nesse sentido, este trabalho avança no entendimento de como esses aspectos políticos - quase inexplorados pela literatura de aprendizado - interferem e condicionam os processos de aprendizado dos governos na implementação de políticas públicas.

Assim, algumas implicações de política emergem deste trabalho. Em uma perspectiva geral, a principal lição que pode ser dele assimilada é que aumentar a habilidade dos governos de aprender a aprender pode ser o caminho mais apropriado para 
tornar suas estratégias mais efetivas e sustentáveis em médio e longo prazo. Além disso, essa capacidade de aprender deve ser desenvolvida para um contexto em que comportamento e interesses políticos dos agentes são fatores determinantes no processo de aprendizado, e ignorá-los ou tentar suprimi-los do processo pode ser desastroso. Dessa forma, considerando os achados desta pesquisa sobre a dinâmica dos processos de aprendizado nela estudados, é possível especular sobre possíveis maneiras de aumentar a efetividade desses governos em desenvolver suas capacidades de aprender.

Em primeiro lugar, dada a tendência aqui identificada de haver desequilibrio entre o "aprendizado instrumentalista" e o "aprendizado experimentalista" nesses governos, é importante implementar medidas deliberadas para tentar amenizar esse desequilíbrio, ou seja, faz-se necessária a adoção de incentivos e instrumentos para fomentar sistematicamente a experimentação de novas idéias e exercitar o constante questionamento das políticas e estratégias vigentes. Nos casos estudados, por exemplo, a realização de avaliações abrangentes das políticas em questão e a criação de think tanks foram elementos que contribuíram significativamente para o incremento dessa capacidade de experimentação dos governos. Medidas como essas podem ser importantes para aumentar a flexibilidade e adaptabilidade dos governos em ambientes repletos de incertezas e em contínua mutação, como nos que as organizações contemporâneas atuam.

Outra lição que emerge desse trabalho é que o aumento da habilidade de aprender dos governos não depende apenas de aumentar capacidade de aquisição de conhecimento de indivíduos e grupos dentro do aparato burocrático governamental, mas, também, de criar mecanismos eficientes de difusão, socialização e armazenamento desse aprendizado. Além disso, o aprendizado não ocorre apenas no nível das burocracias das administrações públicas; outros agentes também participam do processo, como as elites políticas locais e atores externos às estruturas formais dos governos. Assim, existe também a necessidade de se estabelecerem canais eficientes de comunicação e interação desses diferentes grupos de agentes, possibilitando o fluxo contínuo de informações entre eles e a conciliação de suas opiniões, prioridades e interesses.

Nesse sentido, que outras pesquisas podem ser estimuladas pelos achados deste trabalho? Várias são as possibilidades que podem emergir a depender dos interesses e interpretação de cada pesquisador, mas ressalta-se que três vertentes de pesquisa são especialmente importantes. Primeiramente, parece de fundamental importância ampliar a gama de estudos de casos sobre os processos de aprendizado ocorridos na implementação de políticas públicas, seguindo a mesma linha adotada neste trabalho. Afinal, apesar de o método de estudo de casos ser bastante apropriado para inferir elementos teóricos sobre esse tipo de assunto, ele pouco diz sobre as precondições requeridas para que suas descobertas sejam válidas. Descobrir essas precondições é, portanto, uma tarefa importante. Isso só é possível com a exploração de diversos outros casos, além dos estudados nesta pesquisa. Uma segunda vertente importantíssima e que pode complementar valorosamente os resultados desta pesquisa é a extensão comparativa de suas hipóteses e especulações para organizações do setor privado. Terão os processos de aprendizado nessas organizações características semelhantes às verificadas nesta 
pesquisa para instituições públicas? Principalmente, terá o componente político a mesma importância e impactos similares nos processos de aprendizado dessas organizações? Somente abrangentes e numerosos estudos nesse tipo de organização poderão responder a essas questões.

Por último, e principalmente, um terreno fértil para novas pesquisas que este trabalho faz despertar interesse está relacionado à importância de considerar a heterogeneidade e a diversidade de opiniões, crenças e interesses das instituições dentro dos governos - e, também, das pessoas dentro dessas instituições - na análise do comportamento dos governos e da evolução e dos resultados de suas políticas públicas e de suas ações. Como foi visto, essas diferenças muitas vezes levam a conflitos e disputas internas dentro dos governos, influenciando significativamente seu comportamento e, conseqüentemente, os resultados de suas políticas e ações. $\mathrm{O}$ aprofundamento analítico dessa questão é de fundamental importância para entender o funcionamento dos governos e os processos de desenvolvimento e implementação de suas políticas. Porém, esse é, ainda, um assunto relativamente inexplorado na literatura de desenvolvimento e políticas públicas. Portanto, acredita-se que esse é um tema mais que importante para a realização de novas pesquisas, principalmente, por meio da realização de inúmeros e aprofundados estudos de casos.

(Artigo recebido em outubro de 2007. Versão final em dezembro de 2007.)

\section{Notas}

${ }^{1}$ Neste artigo, não são feitas descrição e análise detalhada e aprofundada sobre essas políticas. O detalhamento delas, incluindo seus processos de implementação e de aprendizado, encontra-se em Rocha (2004), tese de doutorado da qual foi extraído este artigo.

${ }^{2} \mathrm{Na}$ época, o estado tinha, por exemplo, um dos níveis de renda per capita mais baixos do Brasil e do Nordeste.

${ }^{3}$ Essa nova elite política era formada essencialmente por jovens empresários locais, filhos da primeira geração de industriais cearenses. Dentre eles, os empresários Beni Veras, Amarílio Macedo, Sérgio Machado e Tasso Jereissati, que mais tarde viria a ser um dos mais importantes líderes políticos da história recente do estado. A partir de 1978, esses “jovens empresários” assumem a direção do Centro Industrial do Ceará (CIC), dando início à montagem de seu projeto político de combate às elites políticas tradicionais do estado.

${ }^{4}$ Por décadas, o Ceará foi governado por líderes identificados ideologicamente com o regime militar. Os coronéis do exército Virgílio Távora, Adauto Bezerra e César Cals dominavam o cenário político cearense, alternado-se na chefia do poder executivo estadual em sucessivas eleições indiretas.

${ }^{5}$ Esses investimentos foram compartilhados com o governo federal e organismos internacionais como o Banco Mundial e o KFW. Dentre as principais obras, destacam-se a construção do Complexo Portuário do Pecém, a ampliação do Aeroporto Internacional Pinto Martins, a construção do sistema de saneamento básico da cidade de Fortaleza, a construção do Açude do Castanhão, a 
interligação das bacias hidrográficas do estado e a recuperação e ampliação do sistema rodoviário estadual, entre outros.

${ }^{6}$ Por meio, principalmente, da criação de centros formadores de técnicos de nível médio e tecnólogos de nível superior no interior do estado, os Centecs (Centros de Ensino Tecnológico).

${ }^{7}$ O FDI foi criado pela Lei no 10.367, de 07 de Dezembro de 1979. A filosofia desse fundo é de conceder empréstimos equivalentes a certa porcentagem do ICMS recolhido pelas empresas incentivadas, na condição de reembolsá-los após um período de carência. O incentivo dado às empresas manifesta-se, principalmente, no momento do reembolso do empréstimo, quando elas se beneficiam de uma renúncia financeira do governo do estado, que perdoa parte significativa da dívida. Cavalcanti e Prado (1998) denominam "operações triangulares” mecanismos como esse do FDI.

${ }^{8}$ Para se ter uma idéia, quando Tasso Jereissati assumiu o governo, em 1987, o estado gastava apenas com a folha de pagamento cerca de $140 \%$ da arrecadação do ICMS, ou seja, aproximadamente $87 \%$ da receita total do estado (TENDLER, 1997).

${ }^{9}$ No final da década de 70, foi formulado um projeto de nível federal chamado de III Pólo Industrial do Nordeste. Esse projeto tinha como objetivos principais dotar o Ceará de base econômica adequada ao seu desenvolvimento; criar no estado um núcleo dinâmico de irradiação do desenvolvimento econômico por meio da promoção de atividades industriais integradas em termos interindustriais e intersetoriais; promover maior integração das atividades industriais no Nordeste; contribuir para a redução do desemprego urbano no estado e promover o aproveitamento das matérias-primas oriundas do setor primário, com o máximo de agregação de valor no próprio estado. O projeto do III Pólo preconizava que, para induzir os empresários a localizarem atividades industriais no Ceará, seria necessário utilizar uma gama de instrumentos que abrangeria desde a ação promocional até a concessão de incentivos para a implantação e o funcionamento da indústria. Dentre esses incentivos, merecem destaque a oferta de condições de infra-estrutura adequada, o financiamento de longo prazo para formação de capital fixo e de giro, a concessão de incentivos fiscais na forma de isenção ou redução de impostos federais e estaduais e a prestação de assistência técnica às indústrias. Esse projeto, apesar de não ter resultado em ações concretas, possibilitou a realização de estudos e a elaboração de uma agenda política que visava, a partir de investimentos federais e estaduais, transformar o estado em um pólo econômico dinâmico do Nordeste, ao lado da Bahia e de Pernambuco. Acredita-se que, como resultado indireto, esse esforço parece ter fornecido as bases conceituais e institucionais para a política industrial implementada pelo estado nas décadas seguintes.

${ }^{10}$ Dentre eles, o Fundo de Desenvolvimento Industrial (FDI) e a Companhia de Desenvolvimento do Ceará (Codece).

${ }^{11}$ Esses dois aspectos que tornam as políticas de incentivos fiscais atraentes politicamente são observados não apenas no Ceará, mas também em muitos outros estados que utilizam políticas semelhantes.

${ }^{12} \mathrm{O}$ governo do estado do Ceará aumentou seus gastos com subsídios diretos à indústria de menos de 1\% de suas receitas totais no final dos anos 1980 para mais de 15\%, em 2000.

${ }^{13}$ A Secretaria de Desenvolvimento Econômico (SDE) é a agência diretamente responsável pela implementação da política industrial do estado. Contudo, outras agências também têm jogado papéis importantes no desenvolvimento na execução dessa política, principalmente, no que se refere a sua avaliação e controle, merecendo d staque as atuações da Sefaz e da Seplan. Vale ressaltar que, normalmente, a interação dessas agências em envolvido elevado grau de conflito, provavelmente porque seus indicadores de desempenho são diferentes e, de certa forma, até contraditórios. A SDE, como agência executora da política, gr sso modo, persegue metas relacionadas à quantidade de novas indústrias instaladas no estado, endo impactos nos gastos públicos e, também, na arrecadação tributária estadual. A Seplan e a S faz, por outro lado, são avaliadas e cobradas, principalmente, por 
suas capacidades de manter o equilíbrio orçamentário e fiscal do estado, respectivamente. Assim, a intensidade e a forma de execução dessa política têm, entre outras coisas, se mostrado fortemente dependentes da relação de forças entre essas agências.

${ }^{14}$ Desde 1998, a relação percentual entre os gastos com o FDI e a receita de ICMS do estado começou a ultrapassar o limite máximo de $10 \%$ imposto pelo artigo $4^{\circ}$ da Lei $n^{\circ} 10.367$, de 07 de dezembro de 1979, que criou o fundo.

${ }^{15}$ Pois, se o benefício tributário envolve o registro contábil do ICMS, como no caso das "operações triangulares" (como no sistema do FDI do Ceará) em que o imposto é repassado ao governo e posteriormente "devolvido" à empresa na forma de um crédito, via fundo fiscal, o registro do tributo aumenta o coeficiente de vinculação do orçamento. Ou seja, como a receita do ICMS sofre várias vinculações, o aumento da receita do imposto decorrente do seu registro contábil aumenta automaticamente o volume de vinculações. No caso do Ceará, essas vinculações chegam atualmente a mais de 53\% da receita de ICMS do estado. O incremento das vinculações legais causado pelas operações de incentivo à indústria foi da ordem de meio bilhão de reais no período de 1995-2002 nesse estado (Fonte: CED, dados brutos).

${ }^{16}$ Tasso Jereissati, em seu terceiro mandato (1987-1991, 1995-1998 e 1999-2002).

${ }^{17}$ Como, por exemplo, uma possível reação negativa de alguns líderes políticos do governo às ambições políticas do então secretário de Desenvolvimento Econômico, que almejava a vaga de candidato do partido da situação (PSDB) ao governo do estado nas eleições de 2002.

${ }^{18}$ De fato, os gastos com o FDI que em 2000 representavam 15,23\% da arrecadação do ICMS, passaram para 14,5\% em 2001 e para 13,87\%, em 2002.

${ }^{19}$ Os detalhes sobre essa primeira revisão da política de incentivos do Ceará foram extraídos de Amorim, M. A., Amaral Filho, J. e Barbosa, E. (2000). Nova Política Industrial do Ceará. Relatório Técnico.

${ }^{20}$ O CED foi criado pela Lei $\mathrm{n}^{\circ} 13.052$, de 04 de setembro de 2000, como uma autarquia vinculada à Secretaria do Planejamento e Coordenação do Estado do Ceará - Seplan. Sua primeira diretoria foi composta exatamente pelos consultores que realizaram a primeira avaliação da política industrial do estado. Com a mudança de governo no ano de 2003, ele foi fundido com o Iplance, gerando uma nova instituição, o Instituto de Pesquisas e Estratégia Econômica do Ceará - Ipece. É importante ressaltar que essa nova instituição, na prática, colocou em segundo plano as atividades de pesquisa, desenvolvimento e experimentação de novas políticas públicas e estratégias de desenvolvimento para o estado, antes priorizadas pelo CED.

${ }^{21}$ Participaram desse grupo os representantes máximos da Secretaria de Desenvolvimento Econômico, da Secretaria de Planejamento, da Secretaria da Fazenda, da Secretaria de Desenvolvimento Rural, da Secretaria de Agricultura Irrigada, da Secretaria de Ciência e Tecnologia e também do CED. Além disso, freqüentemente, foram convidados representantes de várias instituições públicas e privadas para colaborarem em assuntos específicos, como Sebrae, Federação das Indústrias do Estado do Ceará (FIEC), Associação dos Microempresários do Estado do Ceará.

${ }^{22}$ Após a publicação desse decreto, o estado passou por duas transições de governo consecutivas. A primeira, no dia 06 de abril de 2002, quando o então governad r Tasso J reissati se afastou do cargo para se candidatar a uma vaga no Senado Federal, passando o cargo int rinamente para o vice Beni Veras. A segunda, em janeiro de 2003, quando o governado eleito Lú cio Alcântara (do mesmo grupo político) assumiu o cargo para um mandato de quatro and s (2003-2 j06). A iminência dessas transições foi provavelmente um dos fatores que motivaram realizaç lo dessa segunda reforma e sua institucionalização por meio do Decreto $\mathrm{n}^{\circ} 26.546$, de 44 de abı 1 de 2002, pois o governador que deixava o cargo após dois mandatos consecutivos par cia quere assegurar que os rumos da política industrial do estado contemplariam o aprendizado a umuladd em suas gestões. 
${ }^{23}$ O novo governador é Lúcio Gonçalo de Alcântara (2003-2006), também do grupo político de Tasso Jereissati.

${ }^{24}$ O ProBahia financia até $75 \%$ do ICMS gerado por empreendimentos novos ou que ampliem sua capacidade nos segmentos industriais, agroindustriais, turísticos e de geração de energia elétrica. Os prazos dos financiamentos vão de 6 a 10 anos, cm carência de 3 a 5 anos e juros de $3 \%$ anuais, sem atualização monetária. Esse mecanismo de concessão de incentivos, por se tratar de financiamento concedido por um fundo legalmente constituído, com previsão orçamentária, atende inclusive às exigências da Lei de Responsabilidade Fiscal e da Lei Complementar 24/75. Contudo, com o controle da inflação no País a partir do Plano Real, esse mecanismo de incentivo perdeu sua atratividade, pois a grande vantagem para as empresas era a não atualização monetária das parcelas do financiamento concedido numa época de inflação elevada. Além disso, ele acarreta significativo ônus para o tesouro estadual, pois provoca aumento dos repasses para os fundos constitucionais e outros fundos criados por leis ordinárias, devido a uma arrecadação de ICMS que ocorre apenas escrituralmente para o estado, mas que tem que ser repassada para esses fundos.

${ }^{25}$ A grande vantagem desse sistema em relação ao utilizado no ProBahia é que ele não acarreta em aumento dos repasses para os fundos constitucionais e outros fundos criados por leis ordinárias, além de ser substancialmente mais atrativo para as empresas. Entretanto, a concessão de crédito presumido sempre foi contestada por outros estados da federação por ir de encontro à Lei Complementar 24/75. Após a Lei de Responsabilidade Fiscal, esse mecanismo de incentivo ficou ainda mais comprometido do ponto de vista legal, praticamente inviabilizando sua utilização. Exemplo emblemático dos problemas legais enfrentados com esse mecanismo no estado foi a suspensão do Procobre em razão da ADIN (Ação Direta de Inconstitucionalidade) proposta pelo governo do estado de São Paulo, devido ao uso de crédito presumido no programa.

${ }^{26}$ O Programa "Desenvolve" foi criado pela Lei no 7.980, de 12 de dezembro de 2001, e regulamentado pelo Decreto n 8.205, de 03 de abril de 2002, durante o governo de César Borges.

${ }^{27}$ Antes da Ford, o governo baiano chegou a negociar a vinda da Hyundai e da Asia Motors, que acabaram não concretizando os investimentos no estado.

${ }^{28}$ Para se ter idéia do custo da política de atração de indústrias do estado, observe, por exemplo, que o custo estimado dos incentivos totais dados para atrair a Ford para o estado foi da ordem de 3 bilhões de reais. Cavalcante e Uderman (2003) estimaram que o valor presente dos incentivos oferecidos à montadora estaria entre 2,72 e 2,94 bilhões de reais, o que representaria, por exemplo, cerca de 5\% do PIB do estado em 2001.

${ }^{29}$ Da mesma forma que no Ceará, os executores da política - a SICM - alegavam que a prática de redução ou isenção de ICMS não comprometeria a receita tributária do estado, porquanto esses incentivos seriam dados a empreendimentos industriais que não se instalariam no estado caso eles não fossem concedidos. Entretanto, pelos mesmos motivos que ocorreram no Ceará, essa hipótese foi derrubada no decorrer da implementação da política, ao longo da década de 1990.

${ }^{30}$ Em Pernambuco e no Ceará foram criadas, também, em suas secretarias da Fazenda, "células" específicas paca cuidar dos assuntos relacionados às políticas de incentivos fiscais desses estados. Contudo, em Pernambuco, isso ocorreu na segunda metade dos anos 1990 e, no Ceará, apenas no início da década atual.

${ }^{31}$ Sobretudo por meio da Conder, atualmente subordinada à Secretaria de Desenvolvimento Urbano do Estado.

${ }^{32}$ Principalmente devido à Lei de Responsabilidade Fiscal (Lei Complementar no101, de 04 de maio de 2000) - que estabelece normas de finanças públicas voltadas para a responsabilidade na gestão fiscal, visando prevenir riscos e corrigir os desvios capazes de afetar o equilíbrio das contas 
públicas - e à emergência da reforma tributária brasileira, que começaram a pôr em xeque o uso de incentivos fiscais pelos estados subnacionais brasileiros para atrair investimentos.

${ }^{33}$ O Conselho Nacional de Política Fazendária (Confaz) foi criado em 1975 e existe até os dias de hoje, só que bastante enfraquecido. Sua principal atribuição é promover ações necessárias à elaboração de políticas e harmonização de procedimentos e normas inerentes ao exercício da competência tributária dos estados e do Distrito Federal. Ele é formado por representantes de cada estado e do Distrito Federal - secretários de Fazenda ou eventuais substitutos - e por um representante do governo federal - ministro da Fazenda ou um substituto por ele indicado -, sendo que as decisões do conselho quanto à concessão de isenções, incentivos e benefícios fiscais devem ser todas aceitas por unanimidade (Art. 30). Além disso, a partir da Lei Complementar $\mathrm{n}^{\circ}$ $24 / 75$, os estados não podem mais, em princípio, utilizar o ICMS como instrumento de fomento à industrialização, sem a aprovação prévia do Confaz.

${ }^{34}$ As secretarias de Desenvolvimento Econômico ou de Indústria e Comércio desses estados, diretamente responsáveis pela implementação dessas políticas, foram afastadas inicialmente desse grupo de trabalho, pois, naquele momento, mostravam-se bastante resistentes a qualquer proposta de avaliação ou de mudança nessas políticas.

${ }^{35}$ No âmbito de seu processo de transformação em Agência de Fomento, o Desenbanco vinha implementando um índice que tinha o objetivo de aferir o grau de aderência dos projetos de financiamento apresentados à instituição aos objetivos estratégicos de desenvolvimento do estado, indicados no plano plurianual do governo baiano.

${ }^{36}$ Isso permitia aos estados mais pobres da Região utilizar percentuais de incentivos maiores do que os utilizados por Bahia, Ceará e Pernambuco.

${ }^{37}$ Nesse sistema a empresa incentivada é beneficiada com dilação do prazo de pagamento do saldo devedor mensal do ICMS normal. O incentivo é dado por meio de cláusula que garante à empresa percentuais significativos de desconto sobre o saldo devedor caso ela pague antecipadamente a parcela devida.

${ }^{38}$ Para mais informações sobre a "matriz de desenvolvimento industrial" e "índice de aderência" ver Cavalcante; L.R. M. T.; Argollo, M. S.; 2002.

${ }^{39}$ Os governos desses estados argumentavam que Bahia, Ceará e Pernambuco já possuíam melhores condições de infra-estrutura, maior aglomeração industrial e outros fatores naturais de atração de investimentos e que os estados mais pobres da região não dispunham. Isso os colocaria em desvantagem em relação aos primeiros, que já haviam saído na frente na disputa pelos investimentos. Além disso, muitos desses estados ainda acreditavam que a utilização intensiva de incentivos fiscais não teria custos significativos para os cofres públicos, pois como argumentou o representante do Piauí em uma das reuniões de discussão da proposta, " $100 \%$ de 0 é igual a $0 \%$ de 100 , portanto a política de incentivos fiscais não tem custo para o estado e seríamos bobos em não usá-la agressivamente”.

${ }^{40}$ Naquele momento, alguns executivos do governo baiano, principalmente da Sefaz, DesenBahia e Seplantec, passaram a argumentar que já se fazia necessário desenvolver e implementar um novo modelo de incentivos. Esse modelo deveria atender a três condições essenciais, quais sejam, atratividade para as empresas, sustentabilidade jurídica do mecanismo e viabilidade econômica para o governo.

${ }^{41} \mathrm{O}$ Funcresce financiava investimentos fixos ou de capital de giro com um prazo de oito anos para pagamento e ainda dois anos de carência. Os financiamentos eram equivalentes a $80 \%$ do ICMS pago pelas empresas nos quatro primeiros anos e de $70 \%$ do ICMS para os quatro anos restantes. Além disso, os juros eram de apenas 3\% ao ano sem correção monetária, numa época de inflaçã elevada. Contudo, se os produtos do novo estabelecimento industrial a ser instalado tivessem simila res já sendo produzidos no estado, os percentuais de financiamentos eram reduzidos pela metade. 
${ }^{42}$ Inicialmente, o empresariado local posicionou-se contra o uso de programas de incentivos fiscais pelo governo pernambucano, pois acreditava que isso poderia ser extremamente nocivo para a base industrial já instalada no estado. Contudo, em um segundo momento, em meados da década de 90 , eles inverteram essa postura e passaram a pressionar o governo por incentivos fiscais equivalentes aos que seus concorrentes passaram a receber nos estados vizinhos. Muitos deles até ameaçavam se deslocar para esses estados caso suas reivindicações não fossem atendidas pelo governo de pernambuco.

${ }^{43}$ Mas, na prática, essa política nunca teve o apoio total do governador, cujo perfil, modelo de desenvolvimento e plataforma política estavam mais voltados para ações assistencialistas voltadas às populações carentes do interior do estado.

${ }^{44} \mathrm{Na}$ Bahia e no Ceará, esses consultores são também bastante atuantes e desempenham papel importante fazendo a ponte entre os governos e os investidores, elaborando projetos.

${ }^{45}$ Muitos desses consultores tinham origem dos quadros gerenciais dos próprios órgãos do governo envolvidos na implementação da política, especialmente da $\mathrm{AD} / \mathrm{Diper}$. Isso, de certa forma, facilitava a recuperação da memória perdida.

${ }^{46}$ No período, o governo executou importantes obras de infra-estrutura, tais como a duplicação da BR-232 e a ampliação do Aeroporto Internacional dos Guararapes e do Porto do Suape.

${ }^{47}$ A aprovação desses projetos não implica, porém, a efetiva realização do investimento. Muitos dos projetos de investimentos aprovados pelo Prodepe não chegaram a ser implementados. $\mathrm{O}$ governo de Pernambuco não tem ainda um levantamento de quantos desses projetos chegaram a ser, de fato, executados, resultando na instalação de novos empreendimentos no estado. Contudo, baseado nas experiências do Ceará e da Bahia, acredito que o total de investimentos reais seja bem inferior ao previsto, tomando como base a aprovação desses projetos.

${ }^{48}$ Equivalente a mais de $\mathrm{R} \$ 220$ milhões por ano.

${ }^{49}$ Dos 740 projetos já aprovados no Prodepe, entre 29/09/1996 e 25/10/2002, os principais setores industriais beneficiados foram: eletrometalmecânico ( 99 projetos); plástico ( 89 projetos); minerais não metálicos (87 projetos); agroindústria (78 projetos) e bebidas (71 projetos). Além disso, foram aprovados 71 projetos para instalação de centrais de distribuição e 80 projetos para importadores atacadistas de mercadorias do exterior.

${ }^{50}$ No discurso da maioria dessas pessoas a estratégia de primeira categoria envolveria, entre outras coisas, reforçar os investimentos em infra-estrutura; apoiar setores de serviço modernos e dinâmicos, como a indústria de software e o complexo médico hospitalar do estado; fomentar a difusão e capacitação tecnológica para a indústria local, por meio de centros tecnológicos "vocacionais"; entre outras medidas.

${ }^{51}$ Essa constatação é consistente com os achados de Cassiolato e Brito (2001). Esses autores, baseados nas experiências recentes de alguns estados brasileiros - entre eles, São Paulo, Minas Gerais, Rio de Janeiro, Paraná, Bahia e Ceará - dão um primeiro passo na direção de uma perspectiva mais abrangente da análise das intervenções dos estados subnacionais brasileiros na área industrial, tratandoas, adequadamente, como casos de "políticas industriais descentralizadas". Oportunamente, os autores lembram que "nos últimos anos, a intensificação da atuação dos governos estaduais na criação de estímulos à dinamização das atividades industriais tem ido além da pura concessão de incentivos fiscais às empresas que desejam se instalar na região" (p.1).

${ }^{52}$ Além disso, essa política possui pelo menos dois trunfos que, de certa forma, têm garantido sua sustentabilidade. Primeiro, ela é utilizada como forma de atender às demandas dos prefeitos e líderes políticos regionais por geração de emprego e renda em seus municípios. Segundo, por meio 
dela o governo abre um canal de comunicação e interação com os empresários, elemento essencial nos momentos de arrecadação de fundos para financiamento de campanhas.

${ }^{53}$ Criado pela Lei no 11.288 , de 22 de dezembro de 1995, tinha "a finalidade de fomentar o desenvolvimento industrial, especialmente em relação aos setores considerados relevantes e prioritários para a economia do estado, mediante a concessão de financiamentos nos termos previsto nessa Lei" $\left(\right.$ Art. $\left.1^{\circ}\right)$.

${ }^{54}$ Esse centro era uma espécie de think tank que deveria cumprir dupla missão. A primeira era acompanhar e promover a melhoria contínua da política de incentivos fiscais do estado. A segunda era de funcionar como centro gerador de idéias e estratégias inovadoras para o desenvolvimento sustentável do estado, que complementassem a política de incentivos fiscais.

${ }^{55}$ Tanto dos grupos de interesse envolvidos nos processos de negociação e barganha política como as instituições que disputam posições dentro dos governos.

\section{Referências bibliográficas}

Amaral Filho, J. do.. Incentivos fiscais e políticas estaduais de atração de investimentos. Texto para discussão. Ceará: Ipece, 2003.

Arbix, G.. Políticas do desperdício e assimetria entre público e privado na indústria automobilística. Revista Brasileira de Ciências Sociais. Rio de Janeiro, v.17, n.48. pp. 109-129, 2002. ArgYris, C.; SCHÖN, D.. Organizational learning: A theory of action perspective. Reading, Mass: Addison Wesley, 1978.

Cassiolato, J.E.; Brito, J.. Políticas industriais descentralizadas no caso brasileiro: uma breve análise da experiência recente. Texto apresentado no Seminário "Camino a la Competitividad: el Nivel Meso y Micro económico. Santiago, Chile: Cepal/BID, 2001. Cavalcante, L.R. M. T.; Argollo, M. S. Índice de aderência: uma proposta de aferição dos impactos econômicos e sociais de projetos de investimentos. Salvador: Fundação Luis Eduardo Magalhães. Disponível em: http://www.flem.org.br/premio/resultadofinal/ pflemprj10054.pdf. Acesso em 10 julho, 2002.

Cavalcanti, C. E. G.; Prado, S.. Aspectos da Guerra Fiscal no Brasil. São Paulo: Ipea/ Fundap, 1998.

Dias, F. R. C.; Holanda, M. C.; Amaral Filho, J.. do. Base conceitual dos critérios para concessão de incentivos pa a investimento no Ceará-FDI. Nota Técnica N.3, Instituto de Pesquisa e Estratégia Econôm ca (Ipece). Fortaleza, 2003.

Easti Rby-Smith, M.; Araujo, L.; Burgoyne J.. Organizational learning and the learning organi ation. London: page, 1999.

MArd I, James G.. Exploration and exploitation in organizational learning. Organization Scienc v. 2, n.1, fev., 1991.

Roch , A. G. T.. Os governos aprendem, as políticas evoluem: fatores cognitivos e políti os moldando as políticas industriais da Bahia, do Ceará e de Pernambuco. Tese de 
Doutorado. Departamento de Engenharia Industrial (DEI). Pontifícia Universidade Católica do Rio de Janeiro (PUC-Rio). Rio de Janeiro, set., 2004.

SEnge, P.. The fifth discipline: The art and practice of the learning organization. London: Random House, 1990. 


\section{Resumo - Resumen - Abstract}

\section{O aprendizado organizacional na implementação de políticas públicas industriais em três estados nordestinos. \\ Antônio Glauter Teófilo Rocha}

O objetivo deste artigo é ampliar o conhecimento atual sobre os processos de aprendizado na implementação de políticas públicas, procurando entender, em especial, os aspectos políticos envolvidos nesses processos e como eles influenciam a evolução e os resultados dessas políticas. Nesse sentido, com base em estudos de casos realizados sobre as políticas industriais implementadas pelos estados da Bahia, do Ceará e de Pernambuco nas últimas décadas, conclui-se que o aprendizado de indivíduos e grupos isoladamente dentro dos governos não parece garantir um efetivo aprendizado do governo na implementação de suas políticas. Nos casos estudados, o aprendizado organizacional mostra-se como um processo no qual aspectos políticos e cognitivos interagem sob as restrições de arranjos institucionais específicos. Esses aspectos políticos tanto podem filtrar, retardar e até mesmo impedir a assimilação organizacional do aprendizado de indivíduos ou de grupos, como, outras vezes, podem acelerá-lo.

Palavras-chave: Políticas públicas; políticas industriais; aprendizado organizacional; aspectos políticos.

\section{El aprendizaje organizacional en la implementación de políticas públicas industriales} en tres provincias del nordeste brasileño.

Antônio Glauter Teófilo Rocha

El objetivo de este artículo es ampliar los conocimientos actuales sobre los procesos de aprendizaje que ocurren en la implementación de las políticas públicas, tratando de comprender, en particular, los aspectos políticos en estos procesos y la forma en que ellos influyen en la evolución y resultados de estas políticas. Basándome en estudios de casos realizados en las políticas industriales llevadas a cabo por los gobiernos de las provincias brasileñas de Bahia, Ceará y Pernambuco en las últimas décadas, concluyo que el aprendizaje de los individuos y de los grupos en el gobierno por sí solo no parece garantizar un aprendizaje efectivo del gobierno en la aplicación de sus políticas públicas. En los casos estudiados, el aprendizaje es un proceso en que los aspectos políticos y cognitivos interactúan condicionados por determinadas circunstancias institucionales. Los aspectos políticos pueden filtrar, aplazar e incluso impedir la asimilación organizacional del aprendizaje de los individuos o grupos, y, a veces, pueden acelerarla.

Palavras clave: Políticas públicas; políticas industriales; aprendizaje organizacional; aspectos políticos.

The organizational learning in the implementation of industrial public policies in the Brazilian Northeast states.

Antônio Glauter Teófilo Rocha

This article aims to expand current knowledge on the learning processes that take place in the implementation of public policies, trying to understand, in particular, the politics involved in these processes and how it influences the evolution and results of these policies. Based on case studies carried out on the industrial policies implemented by the Brazilian states of Bahia, Ceara and Pernambuco in recent decades, conclusion points at the fact that the learning of individuals and groups within the government alone does not seem to guarantee an effective learning by the government when implementing its policies. In the cases studied, organizational learning was a process in which politics and cognitive aspects interact under the restrictions of specific institutional 
circumstances. Politics can either filter, delay and even prevent the organizational assimilation of the individuals or groups learning, and, sometimes, may accelerate it.

Key Words: Public policies; industrial policies, organizational learning, political aspects.

Antônio Glauter Teófilo Rocha

Doutor em engenharia de produção (PUC/Rio). Especialista em Políticas Públicas e Gestão Governamental e professor colaborador do Programa de Pós-Graduação em Metrologia, Qualidade e Inovação da PUC/Rio. Contato: e-mail: glauterr@terra.com.br 